\title{
Sex-specific DNA methylation changes in Alzheimer's disease pathology
}

Lanyu Zhang ${ }^{1}$, Juan I. Young ${ }^{2,3}$, Lissette Gomez ${ }^{3}$, Tiago C. Silva ${ }^{1}$, Michael A. Schmidt ${ }^{2,3}$, Jesse Cai ${ }^{4}$, Xi Chen $^{1,5}$, Eden R. Martin ${ }^{2,3}$, Lily Wang ${ }^{1,2,3,5^{*}}$

${ }^{1}$ Division of Biostatistics, Department of Public Health Sciences, University of Miami, Miller School of Medicine, Miami, FL 33136, USA

${ }^{2}$ Dr. John T Macdonald Foundation Department of Human Genetics, University of Miami, Miller School of Medicine, Miami, FL 33136, USA

${ }^{3}$ John P. Hussman Institute for Human Genomics, University of Miami Miller School of Medicine, Miami, FL 33136, USA

${ }^{4}$ Brentwood High School, 5304 Murray Ln, Brentwood, TN 37027

${ }^{5}$ Sylvester Comprehensive Cancer Center, University of Miami, Miller School of Medicine, Miami, FL 33136, USA

* To whom correspondence should be addressed.

Corresponding Address:

Lily Wang

Soffer Clinical Research Ctr

University of Miami School of Medicine

1120 NW 14th St

Miami, Florida 33136-2107

Tel: 305-243-2927; Fax: 305-243-5544;

Email: lily.wangg@gmail.com 
medRxiv preprint doi: https://doi.org/10.1101/2021.03.01.21252029; this version posted March 2, 2021. The copyright holder for this preprint (which was not certified by peer review) is the author/funder, who has granted medRxiv a license to display the preprint in perpetuity.

It is made available under a CC-BY-NC-ND 4.0 International license .

\section{Abstract}

Sex is an important factor that contributes to the clinical and biological heterogeneities in Alzheimer's disease (AD), but the regulatory mechanisms underlying sex disparity in AD are still not well understood. DNA methylation is an important epigenetic modification that regulates gene transcription and is known to be involved in AD. We performed the first large-scale sex-specific meta-analysis of DNA methylation changes in $\mathrm{AD}$, by re-analyzing four recent epigenome-wide association studies totaling more than 1000 postmortem prefrontal cortex brain samples using a uniform analytical pipeline. For each cohort we employed two complementary analytical strategies, a sex-stratified analysis that examined methylationBraak stage associations in male and female samples separately, and a sex-by-Braak stage interaction analysis that compared the magnitude of these associations between different sexes. Our analysis uncovered 14 novel CpGs, mapped to genes such as TMEM39A and TNXB that are associated with AD in a sex-specific manner. TMEM39A is known to be involved in inflammation, dysregulated type I interferon responses, and other immune processes. $T N X B$ encodes tenascin proteins, which are extracellular matrix glycoproteins demonstrated to modulate synaptic plasticity in the brain. Moreover, for many previously implicated AD genes, such as $M B P$ and $A Z U 1$, our analysis provided the new insights that they were predominately driven by effects in only one sex. These sex-specific DNA methylation changes were enriched in divergent biological processes such as integrin activation in females and complement activation in males. Importantly, a number of drugs commonly prescribed for AD patients also targeted these genes with sex-specific DNA methylation changes. Our study implicated multiple new loci and biological processes that affected AD in a sex-specific manner and highlighted the importance of sex-specific treatment regimens for AD patients.

Key words: Alzheimer's disease, sex-specific, DNA methylation, epigenome-wide association study 
medRxiv preprint doi: https://doi.org/10.1101/2021.03.01.21252029; this version posted March 2, 2021. The copyright holder for this preprint (which was not certified by peer review) is the author/funder, who has granted medRxiv a license to display the preprint in perpetuity.

It is made available under a CC-BY-NC-ND 4.0 International license .

\section{Introduction}

Alzheimer's disease (AD) is the most common cause of dementia. With the aging population in the U.S., $\mathrm{AD}$ has become a major public health concern and one of the most financially costly diseases [1]. Almost two-thirds of AD patients in the U.S. are women [2]. After diagnosis, women also progress faster with more rapid cognitive and functional declines [3-8]. On the other hand, it has also been reported men with AD have increased risk for death [9-11]. However, the molecular mechanisms underlying these observed disparities in AD are still not well understood. Previous studies have shown that epigenetics is an important contributor to the sex differences in brain functions and vulnerability to diseases [12-16]. Among epigenetic modifications, DNA methylation profiles differ significantly between males and females at a number of loci in adult brains [17]. Importantly, alterations of DNA methylation levels have also been implicated in multiple neurological disorders including AD [18-22].

However, thus far, a comprehensive characterization for the contribution of sex to DNA methylation changes in $\mathrm{AD}$ has not been performed. In the identification of sex-specific effects, statistical power is a major challenge [23]. Stratifying by sex reduces the sample size of both groups. Also, comparing methylation to disease associations between the sexes by testing interaction effect would require a much larger sample size than detecting a main effect with the same magnitude [24]. To address these challenges, we performed a comprehensive meta-analysis of more than 1000 post-mortem brain prefrontal cortex samples, collected from four recent AD epigenome-wide association studies [18-21], to identify the most consistent DNA methylation changes affected by AD in a sex-specific manner. As sex is a strong factor in

driving inter-personal variabilities in $\mathrm{AD}$, the results of this study are particularly relevant for precision medicine.

\section{Methods}

\section{Study cohorts}


medRxiv preprint doi: https://doi.org/10.1101/2021.03.01.21252029; this version posted March 2, 2021. The copyright holder for this preprint (which was not certified by peer review) is the author/funder, who has granted medRxiv a license to display the preprint in perpetuity.

It is made available under a CC-BY-NC-ND 4.0 International license .

Our meta-analysis included 1,030 prefrontal cortex brain samples (642 female samples and 388 male samples) from four independent cohorts (Supplementary Table 1), previously described in the ROSMAP [18], Mt. Sinai [20], London [19], and Gasparoni [21] DNA methylation studies.

\section{Pre-processing of DNA methylation data}

As described elsewhere [22], for each cohort quality control included removing probes with detection Pvalue $<0.01$ in all samples and those associated with cigarette smoking [25] or SNPs, and removing samples with low bisulfite conversion efficiency or detected as outliers in principal component analysis (see details in Supplementary Note 1). Next, the QN.BMIQ normalization procedure [26] was performed on the qualitycontrolled methylation data, followed by fitting linear model methylation $\mathrm{M}$ value $~$ methylation slide to remove batch effects. The methylation residuals from these linear models were then used for subsequent analysis.

\section{Single cohort and meta-analysis}

In sex-stratified analysis, for each $\mathrm{CpG}$, we applied the model methylation residuals age at death + Braak stage + CETS estimated neuron proportions [27] to female samples and male samples separately. For the analysis of differentially methylated regions (DMRs), we used the coMethDMR R package [28] to identify co-methylated DMRs associated with Braak stage (Supplementary Note 2), by implementing the same linear model described above. We considered CpGs (or DMRs) with false discovery rate (FDR) less than 0.05 in female samples or male samples to be significant.

To assess inflation of the test statistics, we used quantile-quantile (QQ) plots and estimated genomic inflation factors using both the conventional approach and the bacon method [29] (Supplementary Note 3). The bacon method was also used to obtain inflation-corrected effect sizes, standard errors, and p-values for each cohort, which were then combined by inverse-variance weighted meta-analysis models using $\mathrm{R}$ package meta (Supplementary Note 4). 
medRxiv preprint doi: https://doi.org/10.1101/2021.03.01.21252029; this version posted March 2, 2021. The copyright holder for this preprint (which was not certified by peer review) is the author/funder, who has granted medRxiv a license to display the preprint in perpetuity.

It is made available under a CC-BY-NC-ND 4.0 International license .

In sex-by-Braak stage interaction analysis, for each $\mathrm{CpG}$, we applied the model methylation residuals

$\sim$ age at death + sex + Braak stage + sex*Braak stage + sex*age at death + CETS estimated neuron proportions to samples including both sexes. To select significant CpGs and DMRs, we applied a stagewise analysis approach, previously proposed by van de Berge et al. (2017) [30] (Supplementary Note 5), which was shown to have improved power in high-throughput experiments where multiple hypotheses are tested for each gene.

\section{Enrichment and pathway analysis}

We tested over- and under-representation of significant CpGs and DMRs in different types of genomic regions and chromatin states using Fisher's exact test. Pathway analysis was performed by comparing the genes with significant sex-specific DNA methylation changes in AD with the canonical pathways and biological process GO terms in MSigDB using GSEA analysis [31] (Supplementary Note 6).

\section{Integrative methylation - gene expression analysis}

Integrative methylation - gene expression analysis was performed using the ROSMAP study samples with matched DNA methylation and gene expression data. First, we linked significant CpGs (or DMRs) to nearby genes using GREAT [32]. Next, we removed confounding effects due to batch, age at death, and cell types in methylation data and gene expression data separately by fitting linear models and extracting residuals. Finally, for each gene expression - $\mathrm{CpG}$ (or DMR) pair, we tested the association between gene expression residuals and methylation residuals, adjusting for Braak stage (Supplementary Note 7).

\section{Sex-specific mQTL analysis}

The ROSMAP dataset, imputed to HRC r1.1 reference panel [33], with matched genotype data and DNA methylation data for 688 samples (434 females, 254 males) was used for this analysis. We considered SNPs that are within 500kb from FDR significant CpGs (or DMRs), with MAF $>1 \%$, info score $\geq 0.4$, and are 
medRxiv preprint doi: https://doi.org/10.1101/2021.03.01.21252029; this version posted March 2, 2021. The copyright holder for this preprint (which was not certified by peer review) is the author/funder, who has granted medRxiv a license to display the preprint in perpetuity.

It is made available under a CC-BY-NC-ND 4.0 International license .

significantly associated with AD status $(\mathrm{P}<0.05)$ (Supplementary Note 8). Association between methylation residuals (after removing batch, age at death, and cell type effects) and SNPs were then tested using linear models, adjusting for batch in genotype data and first three PCs estimated from genotype data.

\section{Drug target analysis}

We compared our list of sex-specific DNA methylation changes with targets of drugs prescribed to AD patients or in the development in the ChEMBL database [34] (https://www.ebi.ac.uk/chembl/). To this end, we overlapped genes mapped to significant CpGs or DMRs with the genes targeted by compounds annotated to "Alzheimer Disease" in ChEMBL.

\section{Results}

\section{Description of EWAS cohorts and data}

Among the four cohorts (Supplementary Table 1), the mean age at death ranged from 79.3 to 87.2 years in females and from 67.5 to 85.0 years in males. The number of CpGs and samples removed at each quality control step are presented in Supplementary Table 2. For females, inflation factor lambdas $(\lambda)$ by the conventional approach ranged from 1.060 to 1.154 , and lambdas based on the bacon approach [29] $\left(\lambda_{\text {bacon }}\right)$ ranged from 1.021 to 1.059 (Supplementary Figure 1). Similarly, for males, $\lambda$ ranged from 0.906 to 1.265 , and $\lambda_{\text {bacon }}$ ranged from 0.957 to 1.114 . These values are comparable to those obtained in other recent large scale EWAS [35].

\section{Sex-specific DNA methylation changes in AD}

In sex-stratified analysis, our meta-analysis identified 381 and $76 \mathrm{CpGs}$, mapped to 245 and 51 genes at 5\% FDR in female and male samples, respectively (Figure 1, Table 1, Supplementary Table 3-4). Similarly, we identified 72 and 27 DMRs, mapped to 66 and 22 genes, at 5\% FDR in female and male samples, respectively (Table 2, Supplementary Tables 5-6). Among them, 3.6\% (16 out of 441 unique FDR 
medRxiv preprint doi: https://doi.org/10.1101/2021.03.01.21252029; this version posted March 2, 2021. The copyright holder for this preprint (which was not certified by peer review) is the author/funder, who has granted medRxiv a license to display the preprint in perpetuity. It is made available under a CC-BY-NC-ND 4.0 International license .

significant CpGs) and 12.5\% (11 out of 88 unique FDR significant DMRs) were significant in both females and males with the same direction of change. The average number of CpGs per DMR was $6.5 \pm 8.9$. The FDR significant methylation changes at CpGs and DMRs did not completely overlap. Only 89 out of the $381(23.4 \%)$ significant CpGs in females, and 13 out of the 76 (17.1\%) significant CpGs in males overlapped with the significant DMRs. Among all CpGs and all DMRs, the effect estimates in males and females correlated only modestly $\left(r_{\mathrm{CpG}}=0.124, r_{\mathrm{DMR}}=0.170\right)$ and about half $(53 \%$ of CpGs, $54 \%$ of DMRs $)$ were in the same direction of change in males and females, similar to what would be expected by chance.

In sex-by-Braak stage interaction analysis, we identified significant interaction at $14 \mathrm{CpGs}$, but no significant interactions at DMRs at 5\% FDR. There was also little overlap between significant DNA methylation changes identified in sex-stratified and sex-by-Braak stage interaction analyses. Only 4 CpGs were identified by both analyses (Table 3). To understand this discrepancy, note that the sex-stratified analysis detected many changes that are attenuated but might be in the same direction in one sex group compared to the other. For example, among the 10 most significant CpGs from the sex-stratified analysis, 9 female-specific and 6 male-specific CpGs (Table 1) had the same direction of methylation-Braak stage association in both sexes. On the other hand, in sex-by-Braak stage interaction analysis, 13 out of the 14 significant $\mathrm{CpGs}$ had the opposite directions of changes for methylation-Braak stage associations in females and males (Table 3). Therefore, the interaction analysis was able to identify CpGs (or DMRs) with large differences in sex-specific effect estimates, often in different directions, but these effects might not have reached FDR significance in sex-stratified analysis. For example, from Table 3, the CpG with the most significant interaction (cg13212831) had effect estimates 0.083 and -0.139 for females and males, respectively. In sex-stratified analysis, although the methylation-Braak stage associations were highly significant $\left(\mathrm{P}-\right.$ value $_{\text {female }}=0.006, \mathrm{P}$ - value $\left._{\text {male }}=4.1 \times 10^{-5}\right)$, they did not reach 5\% FDR significance threshold $\left(\mathrm{FDR}_{\text {female }}=0.413, \mathrm{FDR}_{\text {male }}=0.097\right)$. Therefore, the results from sex-stratified analysis and sex-by-Braak stage interaction analysis complemented each other.

Consistent with previous studies $[18,19,36,37]$, we observed the majority of these sex-specific changes were hyper-methylated in AD samples, for which methylation levels increased as AD Braak stage 
medRxiv preprint doi: https://doi.org/10.1101/2021.03.01.21252029; this version posted March 2, 2021. The copyright holder for this preprint (which was not certified by peer review) is the author/funder, who has granted medRxiv a license to display the preprint in perpetuity.

It is made available under a CC-BY-NC-ND 4.0 International license .

increased. More specifically, 59\% of the significant CpGs and $69 \%$ of the significant DMRs in females, along with $66 \%$ of the significant CpGs and $89 \%$ of the significant DMRs in males were hyper-methylated in $\mathrm{AD}$ (Supplementary Table 3-6).

\section{Enrichment analysis of sex-specific DNA methylation changes in different genomic features}

Compared to background probes, significant hypermethylated DMRs and CpGs in females are overrepresented in $\mathrm{CpG}$ islands and gene bodies and under-represented in open sea and intergenic regions (Supplementary Figure 2a, Supplementary Table 7). In contrast, significant hypermethylated DMRs and CpGs in males are over-represented in shores, 5'UTRs and TSS1500s, but under-represented in open seas, gene bodies, and intergenic regions.

Significant hypomethylated changes in females are over-represented in open seas, but underrepresented in CpG islands, TSS200s, and intergenic regions, while significant hypomethylated changes in males are over-represented in open seas (Supplementary Figure 2b, Supplementary Table 7). Interestingly, compared to males, significant hyper-methylated changes in females are more likely to occur in CpG islands and gene bodies and less likely to occur in shores and 5'UTRs. On the other hand, significant hypomethylated CpGs in females are less likely to occur in $\mathrm{CpG}$ islands.

Our enrichment analysis with respect to chromatin states showed that significant hyper-methylated changes in females were enriched in bivalent enhancer, flanking active TSS, repressed polycomb, and transcription at gene 5' and 3' regions, but depleted in quiescent/low, strong transcription, weakly repressed polycomb, and weak transcription regions (Supplementary Figure 2c, Supplementary Table 8). In contrast, significant hypermethylated changes in males were enriched in active TSS, flanking active TSS, and repressed polycomb regions, but depleted in quiescent/low, strong transcription, weak repressed polycomb, and weak transcription regions.

Hypomethylated changes in females were enriched in enhancers, weak repressed polycomb, and weak transcription regions, but depleted in active TSS, bivalent/poised TSS, and repressed polycomb regions, while hypomethylated changes in males were enriched in flanking active TSS and weak repressed 
medRxiv preprint doi: https://doi.org/10.1101/2021.03.01.21252029; this version posted March 2, 2021. The copyright holder for this preprint (which was not certified by peer review) is the author/funder, who has granted medRxiv a license to display the preprint in perpetuity.

It is made available under a CC-BY-NC-ND 4.0 International license .

polycomb regions (Supplementary Figure 2d, Supplementary Table 8). Compared to males, significant hyper-methylated changes in females are more likely to occur at bivalent enhancer and flaking active TSS, but less likely to occur in active TSS, flanking bivalent TSS/Enh, and quiescent/low regions, while significant hypomethylated changes in females are less likely to occur at active TSS and weakly repressed polycomb regions.

Similarly, enrichment tests for regulatory elements using the LOLA software also supported the potential functional relevance of these significant changes in DNA methylation. Significant DMRs and CpGs in females and males were both enriched in binding sites of EZH2 and SUZ12 (Supplementary Table 9), which are subunits of polycomb repressive complex 2 (PRC2), consistent with the observed enrichment of methylation differences in PRC2 repressed regions (Supplementary Figure 2c,d) and previous observations that DNA methylation often interact with PRC2 binding [38, 39]. Other top hits included binding sites for SPI1, TCF7L2, CEBPB, and CtBP2 in females, and MafK in males.

\section{Gene ontology and pathway analysis}

Because of the relatively smaller number of gene sets being tested, a 25\% FDR significance threshold, instead of the conventional 5\% FDR, was suggested for GSEA [40]. At 25\% FDR, the significant DNA methylation changes in females were enriched in TYROBP causal network (FDR $=0.014)$, TCR signaling in naïve $C D 4+T$ cells $(F D R=0.130)$ and $\mathrm{ROBO}$ receptors bind AKAP5 $(\mathrm{FDR}=0.160)$ gene sets, and significant methylation changes in males were enriched in initial triggering of complement gene set (FDR $=0.245$ ). The TYROBP causal network was previously inferred from a large-scale network analysis of human LOAD brains [41]; it was FDR significant (P-value $<0.001, \mathrm{FDR}=0.014)$ in females (Supplementary Figure 3a), compared to a nominal association in males (P-value $<0.001, \mathrm{FDR}=0.620)$. Interestingly, the core enrichment subset of genes identified by GSEA in the female and male subnetworks regulated by TYROBP involved DNA methylation changes at different genes (Supplementary Figure 3b), highlighting different regulatory mechanisms for this gene network in males and females. 
medRxiv preprint doi: https://doi.org/10.1101/2021.03.01.21252029; this version posted March 2, 2021. The copyright holder for this preprint (which was not certified by peer review) is the author/funder, who has granted medRxiv a license to display the preprint in perpetuity.

It is made available under a CC-BY-NC-ND 4.0 International license .

The comparison with gene ontology (GO) terms showed at 25\% FDR, significant methylation changes in females were enriched in 25 GO biological processes (Table 4, Supplementary Table 10), many of which are involved in inflammatory responses associated with AD pathology including CD8 positive alpha beta $T$ cell activation and interferon alpha production, as well as other biological processes critical for AD pathogenesis such as response to platelet derived growth factor and positive regulation of axon extension. For males, we did not identify any significant GO terms at 25\% FDR; the strongest enrichment with nominal P-value less than 0.001 involved immune responses to the accumulation of amyloid- $\beta(A \beta)$ in the brain, such as regulation of T cell activation via T cell receptor contact with antigen bound to MHC molecule on antigen presenting cell, and other biological processes recently implicated in $\mathrm{AD}$ such as response to angiotensin $[42,43]$ and cell redox homeostasis $[44,45]$.

\section{Correlation of sex-specific DNA methylation changes in AD with expression levels of nearby genes}

Using the ROSMAP dataset with 529 samples (333 females and 196 males) with both DNA methylation and RNA-seq gene expression data, we next evaluated the role of significant DMRs or CpGs by correlating their DNA methylation levels to the expression of genes linked by GREAT [32], which associates genomic regions to target genes. At 5\% FDR, for FDR significant $\mathrm{CpGs}$ in females, out of the $381 \mathrm{CpGs}$ that were linked to a nearby gene, 14 were significantly associated with target gene expression levels (Supplementary Table 11), and half of them $(n=7)$ had effects in the negative direction. Among FDR significant CpGs in males, out of the $46 \mathrm{CpGs}$ that were linked to a nearby gene, 2 were significantly associated with target gene expression and both were in the negative direction. Notably, in females, several of the most significant CpG methylation-gene expression associations were observed for the HLA-DPA1 gene, which encodes microglia receptors involved in antigen presentation and is regulated by PU.1 [46]. In males, the most significant CpG-gene expression was for $H L A-D R B 1$, another PU.1 target gene [46]. For the 14 CpGs identified by our sex-by-Braak stage interaction analysis, only one CpG (cg24917065) was significantly associated with target gene (SLC25A37) expressions. 
medRxiv preprint doi: https://doi.org/10.1101/2021.03.01.21252029; this version posted March 2, 2021. The copyright holder for this preprint (which was not certified by peer review) is the author/funder, who has granted medRxiv a license to display the preprint in perpetuity.

It is made available under a CC-BY-NC-ND 4.0 International license .

\section{Correlation and overlap of sex-specific DNA methylation changes in AD with genetic susceptibility}

\section{loci}

To evaluate if the significant methylation differences are located in the vicinity of sex-specific genetic variants implicated in $\mathrm{AD}$, we compared our sex-specific CpGs and DMRs with the recently identified sexspecific SNPs associated with AD biomarkers [47] or AD pathology [48]. We found only 5 CpGs, mapped to the SERP2, KCNE1, TNKS1BP1, FAM165B, PLCB4 genes were located within $500 \mathrm{~kb}$ of the sex-specific SNPs (Supplementary Table 12).

To search for mQTLs, we next tested associations between the sex-specific CpGs and DMRs with SNPs that are located within $500 \mathrm{~kb}$ from them using 688 samples (434 females, 254 males) from the ROSMAP study, which had both genotype and DNA methylation data. While no mQTL-DMR pairs reached 5\% FDR significance, we did identify 572 and 284 FDR-significant mQTL-CpG pairs associated with the sexspecific CpGs in females and males, respectively (Supplementary Tables 13-15). Among the 381 and 76 sex-specific CpGs identified in female and male samples, respectively, 41 (11\%) and 15 (20\%) had at least one corresponding mQTL in brain samples. Among the 14 CpGs identified in our sex-by-Braak stage interaction analysis, 2 and 7 CpGs with at least one brain mQTL, corresponding to 21 and 236 significant mQTL-CpG pairs, were identified at 5\% FDR in females and males, respectively.

\section{Drug target analysis of sex-specific DNA methylation changes}

To investigate the clinical impact of the sex-specific DNA methylation changes, we next compared them with targets of drugs in the ChEMBL database [34] that are annotated to Alzheimer disease, many of which are antipsychotic medications commonly prescribed to AD patients for treating psychiatric symptoms that accompany AD. We found that 13 CpGs and 2 DMRs, mapped to 20 genes, had overlap with targets of 16 different drugs (Supplementary Table 16). Among them, CACNA1C encodes voltage-dependent calcium channel, which is a target of cholinesterase inhibitor donepezil. Previously, drug response for donepezil were shown to be modulated by the sex hormone estrogen receptor alpha (ESR1) genotype [49]. Also, 
medRxiv preprint doi: https://doi.org/10.1101/2021.03.01.21252029; this version posted March 2, 2021. The copyright holder for this preprint (which was not certified by peer review) is the author/funder, who has granted medRxiv a license to display the preprint in perpetuity.

It is made available under a CC-BY-NC-ND 4.0 International license .

CHRM3 encodes muscarinic acetylcholine receptor, which is targeted by two commonly prescribed antipsychotic drugs for AD patients, trazodone and haloperidol. In both human and animal models, it has been observed treatment with haloperidol induces sex-specific DNA methylation changes [50, 51]. Several CpGs and one DMR are mapped to targets of valproic acid, a mood stabilizer often prescribed for AD patients and was shown to have different pharmacokinetic profiles between male and female subjects [52]. Interestingly, two CpGs and 1 DMR also mapped to targets of caffeine, which was included in cocktail therapy in AD clinical trials $[53,54]$. Although caffeine reduces the risk for $\mathrm{AD}[55,56]$ in both men and women, the protective effect seem to be greater in women [57]. Taken together, these results highlighted the clinical importance of the sex-specific DNA methylation changes.

\section{Discussion}

To identify sex-specific changes in AD, we employed two complementary approaches, a sex-stratified analysis that examined methylation-Braak stage associations in female and male samples separately, and a sex-by-Braak stage interaction analysis that compared the magnitude of these associations between different sexes. In sex-stratified analysis, as discussed above, a substantial number of the significant loci showed the same direction but attenuation of effect size for methylation-Braak stage association in a different sex (Table 1 and 2). Therefore, it is not surprising that many of these significant CpGs were identified previously in sex-combined meta-analysis [22]. Among FDR significant methylation changes in females, 325 CpGs (85\%) and 40 DMRs (56\%), mapped to genes such as $H O X A 3, A Z U 1$, and $M B P$, were also previously identified in our sex-combined meta-analysis [22] (Supplementary Tables 3 and 5). Similarly, in the analysis of male samples, among FDR significant changes, 58 (76\%) CpGs and 15 DMRs (56\%), mapped to genes such as MAMSTR, RHBDF2, and $A G A P 2$, overlapped with significant hits from sex-combined meta-analysis [22] (Supplementary Tables 4 and 6). However, our sex-specific analysis 
medRxiv preprint doi: https://doi.org/10.1101/2021.03.01.21252029; this version posted March 2, 2021. The copyright holder for this preprint (which was not certified by peer review) is the author/funder, who has granted medRxiv a license to display the preprint in perpetuity. It is made available under a CC-BY-NC-ND 4.0 International license .

provided the new insight that the effects of these known AD genes appear to be predominately driven by effects in only one sex (Table 1 and 2).

On the other hand, our sex-specific analysis also uncovered novel methylation changes at $84 \mathrm{CpGs}$ and 42 DMRs that were not identified previously by sex-combined analyses[22], which might have reduced power due to heterogeneity between the sexes. For example, among the top $10 \mathrm{CpGs}$ in the sex-stratified analysis (Table 1), a new locus at cg22632947, which mapped to the gene body of the PRKCA gene, was highly significant in female samples (estimate $=-0.139, \mathrm{P}$-value $=1.50 \times 10^{-7}, \mathrm{FDR}=3.00 \times 10^{-3}$ ), but not significant in male samples (estimate $=-0.005, \mathrm{P}$-value $=0.857, \mathrm{FDR}=0.995)($ Supplementary Figure 4$)$. The PRKCA gene encodes protein kinase $\mathrm{C} \alpha(\mathrm{PKC} \alpha)$, which participates in synaptic loss resulting from accumulation of amyloid- $\beta(\mathrm{A} \beta)$ in $\mathrm{AD}[58,59]$. Another novel locus is at $\operatorname{cg} 18942110$ in the promoter of the CRTC3 gene, where methylation-Braak stage association was highly significant in male samples $\left(\right.$ estimate $=-0.164, \mathrm{P}$-value $\left.=2.23 \times 10^{-6}, \mathrm{FDR}=3.19 \times 10^{-2}\right)$, but not significant in female samples (estimate $=-0.031$, P-value $=0.306$, FDR $=0.952)($ Supplementary Figure 4$)$. CRTC3 is a member of the CRTC family, which are coactivators of the transcription factor CREB (cAMP-response element binding protein). In addition to its crucial role in maintaining synaptic plasticity and facilitation of short-term memory to long term memory, the CREB signaling pathway also mediates synapse loss induced by $\mathrm{A} \beta$ in $\mathrm{AD}[60]$. Notably, synapse loss significantly correlates with cognitive impairment $[61,62]$ and has been observed to be an early feature of AD pathogenesis $[63,64]$.

The sex-by-Braak stage interaction analysis also uncovered a number of additional novel methylation loci that affected $\mathrm{AD}$ in a sex-specific manner. Notably, none of the $14 \mathrm{CpGs}$ detected in our interaction analysis were identified in previous large-scale DNA methylation studies [18-22], suggesting that sexspecific changes such as these can be missed by conventional studies that do not consider the impact of sex. This is likely due to cancelation of effects in sex-combined analysis, because the majority of these 14 CpGs had different directions of methylation-Braak stage effects in male and female samples (Table 3). Among genes mapped to these 14 CpGs, TMEM39A is a member of the transmembrane (TMEM) protein family. In recent GWAS, a genetic variant on TMEM39A was discovered and replicated as an important risk locus 
medRxiv preprint doi: https://doi.org/10.1101/2021.03.01.21252029; this version posted March 2, 2021. The copyright holder for this preprint (which was not certified by peer review) is the author/funder, who has granted medRxiv a license to display the preprint in perpetuity. It is made available under a CC-BY-NC-ND 4.0 International license .

for multiple sclerosis, an autoimmune condition of the central nervous system $[65,66]$. While relatively little is known about the role of TMEM39A in $\mathrm{AD}$, given its important contributions to inflammation, dysregulated type I interferon responses, and other immune processes [67] which are also implicated in $\mathrm{AD}$, methylation differences affecting this gene are particularly relevant. Another noteworthy gene is $T N X B$ and its pseudo gene $T N X A$, which are located in the major histocompatibility complex (MHC) class III region on chromosome 6. TNXB encodes tenascin proteins, which are extracellular matrix glycoproteins demonstrated to modulate synaptic plasticity in the brain [68]. In particular, genetic variants at the $H L A$ $D Q B 1$ locus discovered in the recent AD genetic meta-analysis [69] included eQTLs for TNXB/TNXA in brain tissues $[69,70]$.

To better understand the relevance of these AD-associated sex-specific changes, we also compared our results with several previous studies. The comparison with Xia et al. (2019) [16] and Xu et al. (2014) [17], which examined differential methylation between males and females in the prefrontal cortex, but without considering $\mathrm{AD}$ status $[16,17]$, showed our results were largely distinct. Among 451 unique CpGs identified in our sex-stratified analysis or sex-by-Braak stage interaction analysis, only 16 were also identified in Xia et al. (2019) [16] and none were identified in Xu et al. (2014) [17] (Supplementary Tables 3-6). This is probably due to different hypotheses tested in our study and the sexual dimorphism studies while our study examined the impact of sex on methylation-Braak stage association, the previous studies examined differential methylation between the sexes, regardless of AD severity. The comparison of our results with sex-specific DNA methylation changes in fetal brain development $[71,72]$ also showed very little overlap (Supplementary Table 17); one hypothesis could be that the AD-associated sex-specific DNA methylation changes identified in this study might be influenced by environmental risk factors for $\mathrm{AD}$, such as diet and exercise.

The results of our gene set analysis highlighted a number of critical sex-specific biological processes in AD. Notably, the TYROBP causal network reached FDR significance threshold in females (FDR = 0.014) but was only nominally significant in males. Interestingly, AD- associated CpG methylation changes that drove pathway associations (core enrichment genes) occurred at different genes in females and males 
medRxiv preprint doi: https://doi.org/10.1101/2021.03.01.21252029; this version posted March 2, 2021. The copyright holder for this preprint (which was not certified by peer review) is the author/funder, who has granted medRxiv a license to display the preprint in perpetuity. It is made available under a CC-BY-NC-ND 4.0 International license .

(Supplementary Figure 3), indicating a potentially sex-specific regulatory mechanism for this network. TYROBP (TYRO protein tyrosine kinase-binding protein) is a key regulator of the complement pathway in the immune/microglia network, which is activated as $\mathrm{A} \beta$ accumulates in LOAD brains [41, 73]. TYROBP is a transmembrane adaptor protein for TREM2, SIRP $\beta 1$, and CR3 receptors, which are known to be involved in AD pathogenesis [73-75]. In addition, TYROBP is regulated by SPI1, a central hub for the network of genes involved in myeloid immune response in neurodegeneration [76]. In patients with LOAD, TYROBP was observed to be up-regulated in the brains in multiple cohorts [41]. Recent studies suggested TYROBP-mediated signaling is involved in multiple important functions as aggregating A $\beta$ activates microglia, including enhanced phagocytosis of damaged neurons [41, 73] and suppression of inflammatory responses [77], as well as neuronal pruning activity [41]. Interestingly, in gene ontology (GO) analysis, among the most significant GO Biological Process terms (P-value $<0.001)$ in females and males, none of them overlapped (Supplementary Table 10), even though the relevancy of all the top biological processes were supported by recent AD literature (Table 4). These results suggest different biological processes are associated with $\mathrm{AD}$ pathology in males and females.

Importantly, a number of these sex-specific biological processes pointed to important potential biomarkers and therapeutic targets for the treatment of $\mathrm{AD}$. For example, one of the top biological process enriched with significant methylation changes in female samples is response to platelet derived growth factor. Recently, multiple studies have shown that reduced levels of platelet-derived growth factors (PDGFs) in plasma significantly correlate with mild cognitive impairment and so have proposed PDGFs as a potential biomarker for $\mathrm{AD}[78,79]$. For the significant methylation changes in male samples, one of the top biological process highlighted by our enrichment analysis is dysregulation in the complement system. Recently, a number of novel agents targeting the complement system are being developed and tested in clinical trials for potential effective therapy for $\mathrm{AD}[80]$. Therefore, clinical trials testing potential treatment for $\mathrm{AD}$ patients might have more power for detecting treatment effects by considering sex and targeting the subgroup with the higher predicted benefit based on patient molecular profiles such as DNA methylation. 
medRxiv preprint doi: https://doi.org/10.1101/2021.03.01.21252029; this version posted March 2, 2021. The copyright holder for this preprint (which was not certified by peer review) is the author/funder, who has granted medRxiv a license to display the preprint in perpetuity. It is made available under a CC-BY-NC-ND 4.0 International license .

The comparison with ChEMBL database [34] showed a number of sex-specific DNA methylation changes were also located in regulatory regions of genes targeted by drugs often prescribed to AD patients, such as those treating neuropsychiatric symptoms accompanying AD. Several antipsychotic drugs, such as haloperidol, donepezil and valproic acid had targets in genomic regions where DNA methylation levels associated with $\mathrm{AD}$ in a sex-specific manner. Taken together, these results highlighted the importance of developing and applying sex-specific treatment regimens in AD.

Our study also provided support for the sex-specific effect of brain estrogen in AD. Among FDR significant CpGs in males is cg 15626350, located on the gene body of ESR1 gene, which encodes estrogen receptor alpha, one of two subtypes of estrogen receptor. Genetic polymorphisms of ESRI have been associated with risk of developing cognitive impairment in elders [81-85]. In addition, multiple animal and in vitro studies have demonstrated the neuroprotective effect of estrogen [86,87], which promotes neurogenesis, neuronal plasticity, synaptic transmission and reduces A $\beta$ production. Interestingly, $\operatorname{cg} 15626350$ reached 5\% FDR significance threshold in males (estimate $=0.144, \mathrm{P}$-value $=2.54 \times 10^{-6}$, $\mathrm{FDR}=0.033$, but is only nominally significant in females (estimate $=0.107, \mathrm{P}$-value $=5.08 \times 10^{-4}, \mathrm{FDR}$ $=0.164$ ), indicating a stronger methylation-AD Braak stage association in males (Supplementary Figure 4). Although not statistically significant, cg15626350 also showed stronger association with ESRI gene expression in males $($ estimate $=0.152, \mathrm{P}$-value $=0.067)$ compared to females $($ estimate $=0.031, \mathrm{P}$-value $=$ 0.715). Importantly, the estrogen receptor is targeted by a number of drugs commonly prescribed for AD patients, such as trazodone, haloperidol, valproic acid (Supplementary Table 16). Together with the documented greater prevalence, disease severity and worse outcomes in females to infections and inflammation, particularly in the presence of reduced estradiol levels [88, 89], our findings suggest an interaction between estrogen levels and microglia activities, which may have led to altered inflammatory responses, ultimately resulting in sex differences in vulnerabilities to neurodegeneration in later life stages $[90,91]$. Future experimental studies will help clarify the sex-specific epigenetic mechanisms of the estrogen pathway in modulating AD risk and drug responses. 
medRxiv preprint doi: https://doi.org/10.1101/2021.03.01.21252029; this version posted March 2, 2021. The copyright holder for this preprint (which was not certified by peer review) is the author/funder, who has granted medRxiv a license to display the preprint in perpetuity.

It is made available under a CC-BY-NC-ND 4.0 International license .

There are several limitations for this study. The methylation levels in the studies analyzed here were measured on the bulk prefrontal cortex, which contains a complex mixture of cell types. To reduce confounding effects due to different cell types, we included estimated neuron proportion of each brain sample as a covariate variable in all our analyses. Currently, a challenge with cell-type specific studies is that they are often limited to smaller sample sizes due to labor-intensive sample preparation procedures and therefore have limited statistical power. Also, we did not identify any CpGs or DMRs from chromosome $\mathrm{X}$, this might suggest that sex-differences in $\mathrm{AD}$ are not primarily due to chromosome $\mathrm{X}$. Alternatively, the lack of association might also be due to the limited coverage by the 450k array. Future studies utilizing high throughput sequencing that provides better coverage of the epigenome will help clarify the role of the $\mathrm{X}$ chromosome in $\mathrm{AD}$.

In summary, our study highlights the importance of stratifying on sex and analyzing sex-by-disease interaction in the analysis of DNA methylation data to discover the epigenetic architectures underlying AD. Our meta-analysis discovered a number of novel sex-specific DNA methylation changes consistently associated with AD Braak stage in multiple studies. Because of cancelation of effects in different directions, or dilution from samples with no effect, these sex-specific effects would be missed by sex-combined analysis. Moreover, for many genes previously linked to AD, our work provided evidence that the DNA methylation changes at these genes were predominately driven by effects in only one sex. Our enrichment analysis highlighted divergent biological processes in males and females, which underscored sex-specific regulatory mechanisms involved in AD. Finally, our results also have important implications for precision medicine - many of the sex-specific DNA methylation changes also pointed to important potential AD biomarkers and therapeutic targets, suggesting a pressing need for developing and applying sex-specific treatment strategies for $\mathrm{AD}$. 
Table 1 Top 10 CpGs in sex-stratified analysis. Shown are CpGs that are highly significant in one sex (FDR $<0.05)$, but not significant $(\mathrm{P}$-value $>0.05$ ) in the other sex. For each CpG, annotations include the location of the CpG based on hg19/GRCh37 genomic annotation (chr, position), Illumina gene annotations, nearby genes based on GREAT, and chromatin state. The inverse-variance weighted meta-analysis regression models results include estimated effect size (estimate) where CpGs that are hyper-methylated in AD have positive values, and its associated standard error (se), P-value, and false discovery rate (FDR) for multiple comparison corrections. Bold indicates significant association at 5\% FDR.

\begin{tabular}{|c|c|c|c|c|c|c|c|c|c|c|c|c|c|}
\hline \multirow{2}{*}{ cpg } & \multicolumn{5}{|c|}{ Annotations } & \multicolumn{4}{|c|}{ Female samples } & \multicolumn{4}{|c|}{ Males samples } \\
\hline & chr & position & Illumina & GREAT (distance to TSS) & chromatin state & estimate & $\mathrm{se}$ & P-value & FDR & estimate & se & P-value & FDR \\
\hline \multicolumn{14}{|c|}{ siqnificant only in female samoles } \\
\hline cg09502865 & chr16 & 88600155 & ZFPM1 & ZC3H18(-36633); ZFPM1(+80431, & 1 Active TSS & 0.179 & 0.028 & $2.50 \mathrm{E}-10$ & $1.15 \mathrm{E}-04$ & 0.094 & 0.034 & $4.46 \mathrm{E}-01$ & $9.64 \mathrm{E}-01$ \\
\hline cg05235171 & chr11 & $1.18 \mathrm{E}+08$ & TMPRSS 4 & 4 TMPRSS4(+10301); SCN4B(+654ミ & ミQuiescent/Low & -0.168 & 0.029 & $7.61 \mathrm{E}-09$ & $6.99 \mathrm{E}-04$ & -0.025 & 0.033 & 4.47E-01 & $9.64 \mathrm{E}-01$ \\
\hline cg15610437 & chr19 & 827821 & AZU1 & AZU1(-4) & Weak Repressed PolyCo & $\begin{array}{l}0.155 \\
\end{array}-0-150$ & 0.029 & $5.45 E-08$ & $1.99 \mathrm{E}-03$ & -0.090 & 0.034 & $9.79 \mathrm{E}-02$ & $8.25 \mathrm{E}-01$ \\
\hline cg13572782 & chr18 & 74799495 & MBP & $\mathrm{MBP}(+45229) ; \mathrm{ZNF} 236(+263380)$ & Active TSS & 0.157 & 0.029 & $5.75 E-08$ & $1.99 \mathrm{E}-03$ & 0.047 & 0.036 & $1.90 \mathrm{E}-01$ & $8.92 \mathrm{E}-01$ \\
\hline cg17881200 & chr7 & 27138850 & & HOXA1(-3258) & Repressed PolyComb & 0.152 & 0.029 & $1.41 \mathrm{E}-07$ & $2.98 \mathrm{E}-03$ & 0.131 & 0.034 & $6.22 \mathrm{E}-02$ & $7.73 \mathrm{E}-01$ \\
\hline cg22632947 & chr17 & 64787784 & PRKCA & CACNG5(-43450); PRKCA $(+48884$ & 4 Flanking Active TSS & -0.139 & 0.026 & $1.50 \mathrm{E}-07$ & $3.00 \mathrm{E}-03$ & -0.005 & 0.028 & $8.57 \mathrm{E}-01$ & $9.95 \mathrm{E}-01$ \\
\hline $\operatorname{cg} 15467503$ & chr4 & 1727234 & TACC3 & TMEM129(-4177); TACC3 $(+3969]$ & Weak transcription & -0.146 & 0.028 & $1.81 \mathrm{E}-07$ & $3.45 \mathrm{E}-03$ & -0.083 & 0.034 & $1.33 \mathrm{E}-01$ & $8.59 \mathrm{E}-01$ \\
\hline $\operatorname{cg} 26033526$ & chr6 & 32819858 & TAP1 & PSMB9(-2079); TAP1(+1896) & Genic enhancers & 0.148 & 0.029 & $2.64 \mathrm{E}-07$ & 4.18E-03 & -0.021 & 0.034 & $5.23 \mathrm{E}-01$ & $9.73 \mathrm{E}-01$ \\
\hline cg08363067 & chr16 & 16170085 & ABCC1 & $A B C C 1(+126652) ; A B C C 6(+14723$ & Weak transcription & -0.120 & 0.024 & $7.68 \mathrm{E}-07$ & $7.32 \mathrm{E}-03$ & -0.050 & 0.028 & $7.41 \mathrm{E}-02$ & $7.94 \mathrm{E}-01$ \\
\hline cg12926693 & chr6 & 36665611 & & RAB44(-17644); CDKN1A(+19125 & E Quiescent/Low & -0.149 & 0.030 & $8.59 E-07$ & $7.32 \mathrm{E}-03$ & -0.067 & 0.035 & $5.19 \mathrm{E}-02$ & $7.52 \mathrm{E}-01$ \\
\hline \multicolumn{14}{|c|}{ significant only in male samples } \\
\hline cg07687398 & chr3 & 53198666 & PRKCD & PRKCD(+3531); TKT(+91371) & Weak transcription & 0.052 & 0.030 & $8.63 \mathrm{E}-02$ & $8.19 \mathrm{E}-01$ & 0.183 & 0.035 & 1.16E-07 & $9.88 \mathrm{E}-03$ \\
\hline cg10513118 & chr11 & $1.18 \mathrm{E}+08$ & SCN2B & $\operatorname{SCN} 2 B(+184)$ & Active TSS & 0.038 & 0.030 & $2.01 \mathrm{E}-01$ & $9.17 \mathrm{E}-01$ & 0.172 & 0.033 & $1.42 \mathrm{E}-07$ & $9.88 \mathrm{E}-03$ \\
\hline $\operatorname{cg} 21253952$ & chr8 & $1.44 E+08$ & & ARC(+33833); BAI1 $(+132209)$ & Weak Repressed PolyCo & -0.019 & 0.030 & $5.33 \mathrm{E}-01$ & $9.84 \mathrm{E}-01$ & 0.169 & 0.034 & 4.44E-07 & $1.53 \mathrm{E}-02$ \\
\hline $\operatorname{cg} 18281939$ & chr5 & 77783895 & LHFPL2 & SCAMP1(+127557); LHFPL2(+160 & Weak transcription & -0.022 & 0.029 & $4.55 \mathrm{E}-01$ & $9.76 \mathrm{E}-01$ & -0.179 & 0.036 & $6.26 \mathrm{E}-07$ & $1.79 \mathrm{E}-02$ \\
\hline $\operatorname{cg} 11809272$ & chr6 & 31409361 & & HLA-B(-84398); MICB(-56530) & Quiescent/Low & -0.001 & 0.031 & $9.77 \mathrm{E}-01$ & $1.00 E+00$ & 0.161 & 0.033 & $9.08 \mathrm{E}-07$ & 2.17E-02 \\
\hline $\operatorname{cg} 15952933$ & chr7 & 1899886 & MAD1L1 & ELFN1(+172132); MAD1L1(+372s & Weak transcription & -0.058 & 0.033 & $7.56 \mathrm{E}-02$ & $8.00 E-01$ & -0.156 & 0.032 & $9.48 \mathrm{E}-07$ & 2.17E-02 \\
\hline $\operatorname{cg} 11614451$ & chr3 & 1. $6 \mathrm{E}+08$ & TRIM59 & ENSG00000248710(-113); TRIM! & : Flanking Bivalent TSS/Er & -0.041 & 0.029 & $1.56 \mathrm{E}-01$ & $8.92 \mathrm{E}-01$ & -0.150 & 0.031 & $1.28 \mathrm{E}-06$ & $2.44 \mathrm{E}-02$ \\
\hline $\operatorname{cg} 18942110$ & chr15 & 91072797 & CRTC3 & CRTC3(-502) & Active TSS & 0.031 & 0.030 & $3.06 \mathrm{E}-01$ & $9.52 \mathrm{E}-01$ & -0.164 & 0.035 & $2.23 E-06$ & $3.19 E-02$ \\
\hline cg01655008 & chr14 & 93652954 & C14orf1C & C MOAP1(-1687); TMEM251(+159 & Transcr. at gene 5 and & -0.042 & 0.029 & $1.51 \mathrm{E}-01$ & $8.89 \mathrm{E}-01$ & -0.152 & 0.032 & $2.54 \mathrm{E}-06$ & $3.33 \mathrm{E}-02$ \\
\hline cg02331272 & chr11 & 66964208 & KDM2A & ADRBK1(-69672); KDM2A $(+7705$ & Weak transcription & 0.058 & 0.030 & $1.10 \mathrm{E}-01$ & $8.52 \mathrm{E}-01$ & -0.166 & 0.036 & $2.99 \mathrm{E}-06$ & $3.52 \mathrm{E}-02$ \\
\hline
\end{tabular}


Table 2 Top 10 and 6 DMRs in sex-stratified analysis. Shown are DMRs that are highly significant in one sex (FDR $<0.05$ ), but not significant (P-value $>0.05)$ in another sex. Only 6 DMRs satisfied these criteria in male samples. For each DMR, annotations include location of the DMR based on hg19/GRCh37 genomic annotation (DMR), Illumina gene annotations, nearby genes based on GREAT, and chromatin state. The inversevariance weighted meta-analysis regression models results based on coMethDMR include estimated effect size (estimate) where DMRs that are hyper-methylated in AD have positive values, its associated standard error (se), P-value, and false discovery rate (FDR) for multiple comparison corrections. Shown in bold are significant results with FDR $<0.05$.

\begin{tabular}{|c|c|c|c|c|c|c|c|c|c|c|c|}
\hline \multirow{2}{*}{ DMR } & \multicolumn{3}{|c|}{ Annotations } & \multicolumn{4}{|c|}{ Female samples } & \multicolumn{4}{|c|}{ Male samples } \\
\hline & Illumina & GREAT (distance to TSS) & chromatin state & estimate & se & P-value & FDR & estimate & se & P-value & FDR \\
\hline \multirow{2}{*}{\multicolumn{12}{|c|}{ significant only in female samples }} \\
\hline & & & & & & & & & & & \\
\hline chr5:27038605-27038836 & $\mathrm{CDH} 9$ & $\mathrm{CDH} 9(-28)$ & Active TSS;Flanking Active TSS & 0.128 & 0.024 & $1.87 \mathrm{E}-07$ & $2.30 \mathrm{E}-03$ & 0.077 & 0.027 & $2.74 \mathrm{E}-01$ & 8.99E-01 \\
\hline chr15:31621629-31621843 & KLF13 & KLF13(+2678); OTUD7A(+325806) & Active TSS & 0.115 & 0.023 & 3.30E-07 & $2.30 \mathrm{E}-03$ & 0.042 & 0.027 & $1.19 \mathrm{E}-01$ & 8.07E-01 \\
\hline chr18:74799495-74799572 & MBP & MBP(+45191); ZNF236(+263418) & Active TSS & 0.138 & 0.028 & $5.81 \mathrm{E}-07$ & $2.48 \mathrm{E}-03$ & 0.049 & 0.033 & $1.30 \mathrm{E}-01$ & 8.13E-01 \\
\hline chr7:45066738-45067057 & $\mathrm{CCM} 2$ & $\operatorname{cCM} 2(+273)$ & Weak transcription & -0.125 & 0.026 & 2.23E-06 & $6.20 \mathrm{E}-03$ & -0.090 & 0.027 & $5.51 \mathrm{E}-02$ & $7.00 \mathrm{E}-01$ \\
\hline chr13:67803895-67804060 & PCDH9 & $\mathrm{PCDH9}(+490)$ & Active TSS & -0.088 & 0.019 & 5.04E-06 & $1.02 \mathrm{E}-02$ & -0.017 & 0.022 & 4.40E-01 & 9.50E-01 \\
\hline chr16:66969401-66969506 & CES2;FAM96B & FAM96B(-1151); CES2(+1091) & Flanking Active TSS & 0.115 & 0.025 & $5.68 \mathrm{E}-06$ & $1.02 \mathrm{E}-02$ & 0.052 & 0.028 & $6.52 \mathrm{E}-02$ & $7.28 \mathrm{E}-01$ \\
\hline chr15:40268421-40268777 & EIF2AK4 & EIF2AK4(+42245); SRP14(+62790) & Active TSS & 0.125 & 0.028 & 7.12E-06 & $1.16 \mathrm{E}-02$ & -0.005 & 0.032 & 8.72E- 01 & $9.94 \mathrm{E}-01$ \\
\hline chr5:14492774-14492945 & TRIO & FAM105B(-171997); TRIO(+349049) & Strong transcription & -0.103 & 0.023 & $8.25 \mathrm{E}-06$ & $1.24 \mathrm{E}-02$ & -0.009 & 0.029 & 7.49E- 01 & $9.85 \mathrm{E}-01$ \\
\hline chr17:56736571-56737118 & TEX14 & SEPT4(-118666); TEX14(+32539) & Active TSS & -0.070 & 0.016 & 9.13E-06 & $1.26 \mathrm{E}-02$ & 0.017 & 0.017 & $3.20 \mathrm{E}-01$ & $9.16 \mathrm{E}-01$ \\
\hline chr17:46651722-46651952 & HOXB3 & HOXВ3(-20553); HOXB4(+5636) & Repressed PolyComb & 0.113 & 0.025 & 9.24E-06 & $1.26 \mathrm{E}-02$ & 0.030 & 0.027 & 2.63E-01 & 8.97E-01 \\
\hline \multicolumn{12}{|c|}{ significant only in male samples } \\
\hline chr17:1173700-1173767 & BHLHA9 & BHLHA9(-119) & Weak Repressed PolyComb & -0.041 & 0.025 & 1.07E-01 & 8.23E-01 & -0.118 & 0.026 & $5.08 \mathrm{E}-06$ & $1.59 \mathrm{E}-02$ \\
\hline chr11:68780866-68780984 & MRGPRF & MRGPRF(-48) & Flanking Bivalent TSS/Enh & 0.032 & 0.024 & $1.80 \mathrm{E}-01$ & 8.93E-01 & 0.112 & 0.026 & $1.16 \mathrm{E}-05$ & $2.96 \mathrm{E}-02$ \\
\hline chr12:52437299-52437571 & & C12orf44(-26320); NR4A1(+20819) & Enhancers & 0.009 & 0.017 & $5.93 \mathrm{E}-01$ & 9.93E-01 & 0.075 & 0.017 & $1.38 \mathrm{E}-05$ & 3.31E-02 \\
\hline chr14:89017615-89017776 & PTPN21 & PTPN21(+3381); SPATA7(+165822) & Active TSS & 0.046 & 0.024 & 6.03E-02 & $7.31 \mathrm{E}-01$ & 0.102 & 0.024 & $1.46 \mathrm{E}-05$ & 3.31E-02 \\
\hline chr19:17691465-17691691 & GLT25D1 & COLGALT1(+25175); UNC13A(+107430) & Strong transcription & -0.006 & 0.022 & 8.06E-01 & $1.00 E+00$ & 0.107 & 0.025 & 2.47E-05 & 4.16E-02 \\
\hline chr6:32920567-32921233 & HLA-DMA & ENSG00000248993(-1); HLA-DMA(-1) & Flanking Active TSS; Active TSS; Qui & -0.045 & 0.024 & $3.16 \mathrm{E}-01$ & $9.56 \mathrm{E}-01$ & -0.117 & 0.028 & 3.17E-05 & $4.78 \mathrm{E}-02$ \\
\hline
\end{tabular}


Table 3 Results from sex-by-Braak stage interaction analysis. For each CpG, annotations include the location of the CpG based on hg19/GRCh37 genomic annotation (chr, position), Illumina gene annotations, nearby genes based on GREAT, and chromatin state. The inverse-variance weighted meta-analysis regression models results include estimated effect size (estimate) where CpGs that are hyper-methylated in AD have positive values, its associated standard error (se), and P-value. Adj.pval is adjusted P-value from stageR analysis. Shown in bold are significant results (adj.pval < 0.05 for interaction or P-value $<0.05$ for one sex). * indicates these CpGs also reached 5\% FDR significance in sex-stratified analysis.

\begin{tabular}{|c|c|c|c|c|c|c|c|c|c|c|c|c|c|c|c|}
\hline \multirow{2}{*}{ cpg } & \multicolumn{5}{|c|}{ Annotations } & \multicolumn{3}{|c|}{ Female samples } & \multicolumn{3}{|c|}{ Male samples } & \multicolumn{4}{|c|}{ Sex * Braak stage interaction } \\
\hline & chr & Position & Illumina & GREAT (distance to TSS) & chromatin state & estimate & se & P-value & estimate & se & P-value & estimate & se & P-value & adj.pval \\
\hline cg13212831 & chr1 & 56046343 & & USP24(-365558); PPAP2B(+998897) & Weak transcription & 0.083 & 0.030 & $6.15 \mathrm{E}-03$ & -0.139 & 0.034 & $4.10 \mathrm{E}-05$ & -0.222 & 0.044 & $6.38 \mathrm{E}-07$ & $3.54 \mathrm{E}-04$ \\
\hline cg25734825 & chr3 & 119182523 & TMEMЗ9А & TMEM39A $(+5)$ & Active TSS & 0.059 & 0.030 & $5.01 \mathrm{E}-02$ & -0.156 & 0.036 & $1.21 \mathrm{E}-05$ & -0.220 & 0.045 & $1.12 \mathrm{E}-06$ & $6.22 \mathrm{E}-04$ \\
\hline${ }^{*} \operatorname{cg} 02331272$ & chr11 & 66964208 & KDM2A;KDM2A & ADRBK1(-69672); KDM2A(+77051) & Weak transcriptior & 0.058 & 0.030 & $1.10 \mathrm{E}-01$ & -0.166 & 0.036 & $2.99 \mathrm{E}-06$ & -0.215 & 0.046 & $2.25 \mathrm{E}-06$ & $1.25 \mathrm{E}-03$ \\
\hline cg10622825 & chr1 & 172413349 & PIGC;PIGC;C1orf1C & PIGC(-124) & Active TSS & -0.069 & 0.030 & $2.22 \mathrm{E}-02$ & 134 & 0.034 & $7.78 \mathrm{E}-05$ & 200 & 0.045 & $7.00 \mathrm{E}-06$ & $3.88 \mathrm{E}-03$ \\
\hline cg10784067 & chr16 & 14014435 & ERCC4 & $\operatorname{ERCC} 4(+422)$ & Active TSS & -0.127 & 0.032 & $5.33 \mathrm{E}-05$ & 0.068 & 0.033 & $3.78 \mathrm{E}-02$ & 0.201 & 0.045 & $9.03 \mathrm{E}-06$ & $5.01 E-03$ \\
\hline cg14284055 & chr1 & 24439399 & MYOM3 & МҮОМЗ(-735) & Bivalent Enh & 0.115 & 0.029 & $8.28 \mathrm{E}-05$ & -0.066 & 0.037 & $7.12 \mathrm{E}-02$ & -0.193 & 0.045 & $1.94 \mathrm{E}-05$ & 1.07E-02 \\
\hline${ }^{*} \operatorname{cg} 18942110$ & $\operatorname{chr} 15$ & 91072797 & CRTC3;CRTC3 & CRTC3(-502) & Active TSS & .031 & 0.030 & $3.06 \mathrm{E}-01$ & 0.164 & 0.035 & $2.23 \mathrm{E}-06$ & -0.187 & 0.045 & 3.13E-05 & $1.74 \mathrm{E}-02$ \\
\hline cg09342330 & chr14 & 89021109 & PTPN21;PTPN21 & PTPN21(-33) & Active TSS & 0.045 & 0.030 & $1.31 \mathrm{E}-01$ & -0.144 & 0.037 & $8.30 \mathrm{E}-05$ & -0.189 & 0.046 & $3.47 \mathrm{E}-05$ & $1.93 \mathrm{E}-02$ \\
\hline cg21722170 & chr6 & 31977443 & TNXB;TNXA & C4B $(-5095) ; C 4$ & Quiescent/L & 0.034 & 0.030 & $2.53 \mathrm{E}-01$ & -0.148 & 0.034 & $1.57 \mathrm{E}-05$ & -0.183 & 0.045 & 4.17E-05 & $2.31 \mathrm{E}-02$ \\
\hline cg03662217 & $\operatorname{chr} 21$ & 35747882 & FAM165B & SMIM11(-20) & Active TSS & 0.039 & 0.029 & $1.85 \mathrm{E}-01$ & -0.141 & 0.036 & 7.27E-05 & -0.184 & 045 & $4.59 \mathrm{E}-05$ & $2.55 \mathrm{E}-02$ \\
\hline cg15026265 & chr12 & 28283812 & & PTHLH(-158910 & Quiescent/Low & -0.038 & 0.029 & $95 \mathrm{E}-01$ & 0.1 & .033 & $6.58 \mathrm{E}-05$ & 0.176 & 044 & $72 \mathrm{E}-05$ & 3.73E-02 \\
\hline cg0065 & $\operatorname{chr} 7$ & 86781760 & DMT & DMTF1(-109) & Active TSS & 50 & 0.031 & BE-01 & .130 & .033 & 05 & 8 & 5 & $.95 \mathrm{E}-05$ & $3.86 \mathrm{E}-02$ \\
\hline${ }^{*} \operatorname{cg} 24917065$ & chr8 & 23418389 & $\mathrm{SLC2}$ & SLC25A37(+32072); NKX & Quiescent/Low & -0.135 & 0.030 & 6 & 0.0 & 0.033 & 01 & 0.174 & 14 & -05 & $3.87 \mathrm{E}-02$ \\
\hline${ }^{*} \operatorname{cg} 1$ & chr5 & 77783895 & LHFPL2 & SCAMP1(+127557); LHFPL2(+16075 & Weak transcription & -0.022 & 0.029 & 4.55E-01 & -0.179 & 0.036 & $6.26 \mathrm{E}-07$ & -0.177 & 0.045 & $7.10 \mathrm{E}-05$ & $3.94 \mathrm{E}-02$ \\
\hline
\end{tabular}


Table 4 Top 10 GO Biological processes enriched with sex-specific DNA methylation changes associated with AD Braak stage in females and males. Shown are GSEA results including number of genes in the gene set (SIZE), normalized enrichment score (NES), P-value, FDR and relevant $\mathrm{AD}$ literature for the gene set.

\begin{tabular}{|c|c|c|c|c|c|}
\hline Gene Set & SIZE & NES & P-value & FDR & Relevance to AD \\
\hline \multicolumn{6}{|l|}{ Top 10 GO Biological Process terms in females } \\
\hline INTEGRIN_ACTIVATION & 24 & 2.105 & 0 & $9.53 \mathrm{E}-02$ & $\begin{array}{l}\text { Wennstrome et al. } \\
\text { (2012)[92] }\end{array}$ \\
\hline RESPONSE_TO_PLATELET_DERIVED_GROWTH_FACTOR & 19 & 2.116 & 0 & 1.07E-01 & Sil et al. (2018)[93] \\
\hline I_KAPPAB_PHOSPHORYLATION & 19 & 2.081 & 0 & $1.13 \mathrm{E}-01$ & Jha et al. (2019)[94] \\
\hline NEGATIVE_REGULATION_OF_INTERLEUKIN_8_PRODUCTION & 18 & 2.133 & 0 & $1.21 \mathrm{E}-01$ & Qin et al. (2016)[95] \\
\hline POSITIVE_REGULATION_OF_MACROPHAGE_MIGRATION & 25 & 2.048 & 0 & $1.46 \mathrm{E}-01$ & Bacher et al. (2010) [96] \\
\hline TOLL_LIKE_RECEPTOR_SIGNALING_PATHWAY & 142 & 2.031 & 0 & $1.61 \mathrm{E}-01$ & Fiebich et al. (2018)[97] \\
\hline $\begin{array}{l}\text { NEGATIVE_REGULATION_OF_TUMOR_NECROSIS_FACTOR_SUPERFAMILY_CYTOKINE_PRO } \\
\text { DUCTION }\end{array}$ & 57 & 2.007 & 0 & $1.90 \mathrm{E}-01$ & Chang et al. (2017) [98] \\
\hline REGULATION_OF_SYNCYTIUM_FORMATION_BY_PLASMA_MEMBRANE_FUSION & 28 & 1.944 & 0 & $1.98 \mathrm{E}-01$ & Armoto et al. (2013)[99] \\
\hline RESPONSE_TO_VITAMIN_A & 19 & 1.945 & 0 & $2.08 \mathrm{E}-01$ & Ono et al. (2012)[100] \\
\hline POSITIVE_REGULATION_OF_AXON_EXTENSION & 42 & 1.931 & 0 & $2.08 \mathrm{E}-01$ & Kanaan et al. (2013)[101] \\
\hline \multicolumn{6}{|l|}{ Top 10 Biological Process terms in males } \\
\hline $\begin{array}{l}\text { REGULATION_OF_T_CELL_ACTIVATION_VIA_T_CELL_RECEPTOR_CONTACT_WITH_ANTIGE } \\
\text { N_BOUND_TO_MHC_MOLECULE_ON_ANTIGEN_PRESENTING_CELL }\end{array}$ & 6 & 1.869 & 0 & $5.98 \mathrm{E}-01$ & Schetters et al. (2017)[102] \\
\hline $\begin{array}{l}\text { REGULATION_OF_SYSTEMIC_ARTERIAL_BLOOD_PRESSURE_BY_CIRCULATORY_RENIN_AN } \\
\text { GIOTENSIN }\end{array}$ & 18 & 1.964 & 0 & $6.11 \mathrm{E}-01$ & $\begin{array}{l}\text { Cosarderelioglu et al. } \\
\text { (2020)[42] }\end{array}$ \\
\hline NEGATIVE_REGULATION_OF_REACTIVE_OXYGEN_SPECIES_BIOSYNTHETIC_PROCESS & 29 & 1.745 & 0 & $6.12 \mathrm{E}-01$ & $\begin{array}{l}\text { Manoharan et al. } \\
\text { (2016)[44] }\end{array}$ \\
\hline COMPLEMENT_ACTIVATION & 68 & 1.741 & 0 & $6.26 \mathrm{E}-01$ & Morgan (2018)[80] \\
\hline RESPONSE_TO_ANGIOTENSIN & 26 & 1.746 & 0 & $6.36 \mathrm{E}-01$ & Benigni et al. (2010)[43] \\
\hline CELL_REDOX_HOMEOSTASIS & 55 & 1.721 & 0 & $6.49 \mathrm{E}-01$ & Chen et al. (2020)[45] \\
\hline PROTEIN_DEMETHYLATION & 28 & 1.832 & 0 & 6.77E-01 & Esposito et al. (2019)[103] \\
\hline IMMUNE_RESPONSE_INHIBITING_CELL_SURFACE_RECEPTOR_SIGNALING_PATHWAY & 6 & 1.781 & 0 & $7.02 \mathrm{E}-01$ & Schetters et al. (2017)[102] \\
\hline DICARBOXYLIC_ACID_CATABOLIC_PROCESS & 17 & 2.052 & 0 & 7.57E-01 & Griffin et al. (2017)[104] \\
\hline GLUTAMINE_FAMILY_AMINO_ACID_METABOLIC_PROCESS & 70 & 1.657 & 0 & 7.75E-01 & Conway et al. (2020)[105] \\
\hline
\end{tabular}


medRxiv preprint doi: https://doi.org/10.1101/2021.03.01.21252029; this version posted March 2, 2021. The copyright holder for this preprint (which was not certified by peer review) is the author/funder, who has granted medRxiv a license to display the preprint in perpetuity.

\section{Funding}

This research was supported by US National Institutes of Health grants R21AG060459 (L.W), R01AG061127 (L.W.), R01AG062634 (E.R.M, L.W.), and 1R01AG060472 (E.R.M). The ROSMAP study data were provided by the Rush Alzheimer's Disease Center, Rush University Medical Center, Chicago. Data collection was supported through funding by NIA grants P30AG10161, R01AG15819, R01AG17917, R01AG30146, R01AG36836, U01AG32984, U01AG46152, the Illinois Department of Public Health, and the Translational Genomics Research Institute.

\section{Contributions}

L.W., J.Y., E.R.M., L.Z., T.C.S., L.G. designed the computational analysis. L.Z., T.C.S., L.G., M.S., J.C., L.W. analyzed the data. L.W., J.Y., E.R.M, X.C. contributed to interpretation of the results. L.Z, L.W. wrote the paper, and all authors read and approved the manuscript. L.W. conceived the original idea and supervised the project.

\section{Ethics declarations}

\section{Availability of data and materials}

All datasets analyzed in this study are publicly available as described in Supplementary Table 1. The Mt. Sinai, London, Gasparoni and ROSMAP datasets can be accessed from GEO (accessions GSE80970, GSE59685, GSE66351) and Synapse (DOI:10.7303/syn3157275). The scripts for the analysis performed in this study can be accessed at https://github.com/TransBioInfoLab/ad-meta-analysis-by-sex.

\section{Ethics approval and consent to participate.}

Approval for ROSMAP dataset was obtained through Synapse. The ROSMAP study data were provided by the Rush Alzheimer's Disease Center, Rush University Medical Center, Chicago. Data collection was supported through funding by NIA grants P30AG10161, R01AG15819, R01AG17917, R01AG30146, R01AG36836, U01AG32984, U01AG46152, the Illinois Department of Public Health, and the Translational Genomics Research Institute. The original Religious Orders Study and Rush Memory and Aging Project were approved by Institutional Review Board (IRB) of Rush University Medical Center.

\section{Consent for publication}

Not applicable.

\section{Competing Interest}

The authors declare that they have no conflict of interest. 
medRxiv preprint doi: https://doi.org/10.1101/2021.03.01.21252029; this version posted March 2, 2021. The copyright holder for this preprint (which was not certified by peer review) is the author/funder, who has granted medRxiv a license to display the preprint in perpetuity.

It is made available under a CC-BY-NC-ND 4.0 International license .

\section{References}

[1] M.D. Hurd, P. Martorell, A. Delavande, K.J. Mullen, K.M. Langa, Monetary costs of dementia in the United States, The New England journal of medicine 368(14) (2013) 1326-34.

[2] L.E. Hebert, J. Weuve, P.A. Scherr, D.A. Evans, Alzheimer disease in the United States (2010-2050) estimated using the 2010 census, Neurology 80(19) (2013) 1778-83.

[3] M.E.I. Koran, M. Wagener, T.J. Hohman, I. Alzheimer's Neuroimaging, Sex differences in the association between AD biomarkers and cognitive decline, Brain Imaging Behav 11(1) (2017) 205-213.

[4] J.T. Tschanz, C.D. Corcoran, S. Schwartz, K. Treiber, R.C. Green, M.C. Norton, M.M. Mielke, K. Piercy, M. Steinberg, P.V. Rabins, J.M. Leoutsakos, K.A. Welsh-Bohmer, J.C. Breitner, C.G. Lyketsos, Progression of cognitive, functional, and neuropsychiatric symptom domains in a population cohort with Alzheimer dementia: the Cache County Dementia Progression study, Am J Geriatr Psychiatry 19(6) (2011) 532-42. [5] B.A. Ardekani, A. Convit, A.H. Bachman, Analysis of the MIRIAD Data Shows Sex Differences in Hippocampal Atrophy Progression, J Alzheimers Dis 50(3) (2016) 847-57.

[6] D. Holland, R.S. Desikan, A.M. Dale, L.K. McEvoy, I. Alzheimer's Disease Neuroimaging, Higher rates of decline for women and apolipoprotein E epsilon4 carriers, AJNR Am J Neuroradiol 34(12) (2013) 228793.

[7] K.A. Lin, K.R. Choudhury, B.G. Rathakrishnan, D.M. Marks, J.R. Petrella, P.M. Doraiswamy, I. Alzheimer's Disease Neuroimaging, Marked gender differences in progression of mild cognitive impairment over 8 years, Alzheimers Dement (N Y) 1(2) (2015) 103-110.

[8] X. Hua, D.P. Hibar, S. Lee, A.W. Toga, C.R. Jack, Jr., M.W. Weiner, P.M. Thompson, I. Alzheimer's Disease Neuroimaging, Sex and age differences in atrophic rates: an ADNI study with $n=1368 \mathrm{MRI}$ scans, Neurobiol Aging 31(8) (2010) 1463-80.

[9] E.J. Davis, L. Broestl, S. Abdulai-Saiku, K. Worden, L.W. Bonham, E. Minones-Moyano, A.J. Moreno, D. Wang, K. Chang, G. Williams, B.I. Garay, I. Lobach, N. Devidze, D. Kim, C. Anderson-Bergman, G.Q. Yu, C.C. White, J.A. Harris, B.L. Miller, D.A. Bennett, A.P. Arnold, P.L. De Jager, J.J. Palop, B. Panning, J.S. Yokoyama, L. Mucke, D.B. Dubal, A second X chromosome contributes to resilience in a mouse model of Alzheimer's disease, Sci Transl Med 12(558) (2020).

[10] K.L. Lapane, G. Gambassi, F. Landi, A. Sgadari, V. Mor, R. Bernabei, Gender differences in predictors of mortality in nursing home residents with AD, Neurology 56(5) (2001) 650-4.

[11] Y. Stern, M.X. Tang, M.S. Albert, J. Brandt, D.M. Jacobs, K. Bell, K. Marder, M. Sano, D. Devanand, S.M. Albert, F. Bylsma, W.Y. Tsai, Predicting time to nursing home care and death in individuals with Alzheimer disease, JAMA 277(10) (1997) 806-12.

[12] G.A. Dunn, C.P. Morgan, T.L. Bale, Sex-specificity in transgenerational epigenetic programming, Horm Behav 59(3) (2011) 290-5.

[13] Y. Menger, M. Bettscheider, C. Murgatroyd, D. Spengler, Sex differences in brain epigenetics, Epigenomics 2(6) (2010) 807-21.

[14] M.M. McCarthy, B.M. Nugent, At the frontier of epigenetics of brain sex differences, Front Behav Neurosci 9 (2015) 221.

[15] K.J. Burghardt, J.R. Pilsner, M.J. Bly, V.L. Ellingrod, DNA methylation in schizophrenia subjects: gender and MTHFR 677C/T genotype differences, Epigenomics 4(3) (2012) 261-8.

[16] Y. Xia, R. Dai, K. Wang, C. Jiao, C. Zhang, Y. Xu, H. Li, X. Jing, Y. Chen, Y. Jiang, R.F. Kopp, G. Giase, C. Chen, C. Liu, Sex-differential DNA methylation and associated regulation networks in human brain implicated in the sex-biased risks of psychiatric disorders, Mol Psychiatry (2019).

[17] H. Xu, F. Wang, Y. Liu, Y. Yu, J. Gelernter, H. Zhang, Sex-biased methylome and transcriptome in human prefrontal cortex, Hum Mol Genet 23(5) (2014) 1260-70.

[18] P.L. De Jager, G. Srivastava, K. Lunnon, J. Burgess, L.C. Schalkwyk, L. Yu, M.L. Eaton, B.T. Keenan, J. Ernst, C. McCabe, A. Tang, T. Raj, J. Replogle, W. Brodeur, S. Gabriel, H.S. Chai, C. Younkin, S.G. Younkin, 
medRxiv preprint doi: https://doi.org/10.1101/2021.03.01.21252029; this version posted March 2, 2021. The copyright holder for this preprint (which was not certified by peer review) is the author/funder, who has granted medRxiv a license to display the preprint in perpetuity. It is made available under a CC-BY-NC-ND 4.0 International license .

F. Zou, M. Szyf, C.B. Epstein, J.A. Schneider, B.E. Bernstein, A. Meissner, N. Ertekin-Taner, L.B. Chibnik, M. Kellis, J. Mill, D.A. Bennett, Alzheimer's disease: early alterations in brain DNA methylation at ANK1, BIN1, RHBDF2 and other loci, Nat Neurosci 17(9) (2014) 1156-63.

[19] K. Lunnon, R. Smith, E. Hannon, P.L. De Jager, G. Srivastava, M. Volta, C. Troakes, S. Al-Sarraj, J. Burrage, R. Macdonald, D. Condliffe, L.W. Harries, P. Katsel, V. Haroutunian, Z. Kaminsky, C. Joachim, J. Powell, S. Lovestone, D.A. Bennett, L.C. Schalkwyk, J. Mill, Methylomic profiling implicates cortical deregulation of ANK1 in Alzheimer's disease, Nat Neurosci 17(9) (2014) 1164-70.

[20] R.G. Smith, E. Hannon, P.L. De Jager, L. Chibnik, S.J. Lott, D. Condliffe, A.R. Smith, V. Haroutunian, C. Troakes, S. Al-Sarraj, D.A. Bennett, J. Powell, S. Lovestone, L. Schalkwyk, J. Mill, K. Lunnon, Elevated DNA methylation across a 48-kb region spanning the HOXA gene cluster is associated with Alzheimer's disease neuropathology, Alzheimer's \& dementia : the journal of the Alzheimer's Association 14(12) (2018) 1580-1588.

[21] G. Gasparoni, S. Bultmann, P. Lutsik, T.F.J. Kraus, S. Sordon, J. Vlcek, V. Dietinger, M. Steinmaurer, M. Haider, C.B. Mulholland, T. Arzberger, S. Roeber, M. Riemenschneider, H.A. Kretzschmar, A. Giese, H. Leonhardt, J. Walter, DNA methylation analysis on purified neurons and glia dissects age and Alzheimer's disease-specific changes in the human cortex, Epigenetics Chromatin 11(1) (2018) 41.

[22] L. Zhang, T.C. Silva, J.I. Young, L. Gomez, M.A. Schmidt, K.L. Hamilton-Nelson, B.W. Kunkle, X. Chen, E.R. Martin, L. Wang, Epigenome-wide meta-analysis of DNA methylation differences in prefrontal cortex implicates the immune processes in Alzheimer's disease, Nat Commun 11(1) (2020) 6114. [23] C. Ober, D.A. Loisel, Y. Gilad, Sex-specific genetic architecture of human disease, Nat Rev Genet 9(12) (2008) 911-22.

[24] S.T. Brookes, E. Whitely, M. Egger, G.D. Smith, P.A. Mulheran, T.J. Peters, Subgroup analyses in randomized trials: risks of subgroup-specific analyses; power and sample size for the interaction test, J Clin Epidemiol 57(3) (2004) 229-36.

[25] R. Joehanes, A.C. Just, R.E. Marioni, L.C. Pilling, L.M. Reynolds, P.R. Mandaviya, W. Guan, T. Xu, C.E. Elks, S. Aslibekyan, H. Moreno-Macias, J.A. Smith, J.A. Brody, R. Dhingra, P. Yousefi, J.S. Pankow, S. Kunze, S.H. Shah, A.F. McRae, K. Lohman, J. Sha, D.M. Absher, L. Ferrucci, W. Zhao, E.W. Demerath, J. Bressler, M.L. Grove, T. Huan, C. Liu, M.M. Mendelson, C. Yao, D.P. Kiel, A. Peters, R. Wang-Sattler, P.M. Visscher, N.R. Wray, J.M. Starr, J. Ding, C.J. Rodriguez, N.J. Wareham, M.R. Irvin, D. Zhi, M. Barrdahl, P. Vineis, S. Ambatipudi, A.G. Uitterlinden, A. Hofman, J. Schwartz, E. Colicino, L. Hou, P.S. Vokonas, D.G. Hernandez, A.B. Singleton, S. Bandinelli, S.T. Turner, E.B. Ware, A.K. Smith, T. Klengel, E.B. Binder, B.M. Psaty, K.D. Taylor, S.A. Gharib, B.R. Swenson, L. Liang, D.L. DeMeo, G.T. O'Connor, Z. Herceg, K.J. Ressler, K.N. Conneely, N. Sotoodehnia, S.L. Kardia, D. Melzer, A.A. Baccarelli, J.B. van Meurs, I. Romieu, D.K. Arnett, K.K. Ong, Y. Liu, M. Waldenberger, I.J. Deary, M. Fornage, D. Levy, S.J. London, Epigenetic Signatures of Cigarette Smoking, Circ Cardiovasc Genet 9(5) (2016) 436-447.

[26] T. Wang, W. Guan, J. Lin, N. Boutaoui, G. Canino, J. Luo, J.C. Celedon, W. Chen, A systematic study of normalization methods for Infinium $450 \mathrm{~K}$ methylation data using whole-genome bisulfite sequencing data, Epigenetics 10(7) (2015) 662-9.

[27] J. Guintivano, M.J. Aryee, Z.A. Kaminsky, A cell epigenotype specific model for the correction of brain cellular heterogeneity bias and its application to age, brain region and major depression, Epigenetics 8(3) (2013) 290-302.

[28] L. Gomez, G.J. Odom, J.I. Young, E.R. Martin, L. Liu, X. Chen, A.J. Griswold, Z. Gao, L. Zhang, L. Wang, coMethDMR: accurate identification of co-methylated and differentially methylated regions in epigenome-wide association studies with continuous phenotypes, Nucleic Acids Res 47(17) (2019) e98. [29] M. van Iterson, E.W. van Zwet, B. Consortium, B.T. Heijmans, Controlling bias and inflation in epigenome- and transcriptome-wide association studies using the empirical null distribution, Genome Biol 18(1) (2017) 19. 
medRxiv preprint doi: https://doi.org/10.1101/2021.03.01.21252029; this version posted March 2, 2021. The copyright holder for this preprint (which was not certified by peer review) is the author/funder, who has granted medRxiv a license to display the preprint in perpetuity.

It is made available under a CC-BY-NC-ND 4.0 International license .

[30] K. Van den Berge, C. Soneson, M.D. Robinson, L. Clement, stageR: a general stage-wise method for controlling the gene-level false discovery rate in differential expression and differential transcript usage, Genome Biol 18(1) (2017) 151.

[31] A. Subramanian, P. Tamayo, V.K. Mootha, S. Mukherjee, B.L. Ebert, M.A. Gillette, A. Paulovich, S.L. Pomeroy, T.R. Golub, E.S. Lander, J.P. Mesirov, Gene set enrichment analysis: a knowledge-based approach for interpreting genome-wide expression profiles, Proc Natl Acad Sci U S A 102(43) (2005) 15545-50.

[32] C.Y. McLean, D. Bristor, M. Hiller, S.L. Clarke, B.T. Schaar, C.B. Lowe, A.M. Wenger, G. Bejerano, GREAT improves functional interpretation of cis-regulatory regions, Nat Biotechnol 28(5) (2010) 495501.

[33] S. McCarthy, S. Das, W. Kretzschmar, O. Delaneau, A.R. Wood, A. Teumer, H.M. Kang, C. Fuchsberger, P. Danecek, K. Sharp, Y. Luo, C. Sidore, A. Kwong, N. Timpson, S. Koskinen, S. Vrieze, L.J. Scott, H. Zhang, A. Mahajan, J. Veldink, U. Peters, C. Pato, C.M. van Duijn, C.E. Gillies, I. Gandin, M. Mezzavilla, A. Gilly, M. Cocca, M. Traglia, A. Angius, J.C. Barrett, D. Boomsma, K. Branham, G. Breen, C.M. Brummett, F. Busonero, H. Campbell, A. Chan, S. Chen, E. Chew, F.S. Collins, L.J. Corbin, G.D. Smith, G. Dedoussis, M. Dorr, A.E. Farmaki, L. Ferrucci, L. Forer, R.M. Fraser, S. Gabriel, S. Levy, L. Groop, T. Harrison, A. Hattersley, O.L. Holmen, K. Hveem, M. Kretzler, J.C. Lee, M. McGue, T. Meitinger, D. Melzer, J.L. Min, K.L. Mohlke, J.B. Vincent, M. Nauck, D. Nickerson, A. Palotie, M. Pato, N. Pirastu, M. Mclnnis, J.B. Richards, C. Sala, V. Salomaa, D. Schlessinger, S. Schoenherr, P.E. Slagboom, K. Small, T. Spector, D. Stambolian, M. Tuke, J. Tuomilehto, L.H. Van den Berg, W. Van Rheenen, U. Volker, C. Wijmenga, D. Toniolo, E. Zeggini, P. Gasparini, M.G. Sampson, J.F. Wilson, T. Frayling, P.I. de Bakker, M.A. Swertz, S. McCarroll, C. Kooperberg, A. Dekker, D. Altshuler, C. Willer, W. lacono, S. Ripatti, N. Soranzo, K. Walter, A. Swaroop, F. Cucca, C.A. Anderson, R.M. Myers, M. Boehnke, M.I. McCarthy, R. Durbin, C. Haplotype Reference, A reference panel of 64,976 haplotypes for genotype imputation, Nature genetics 48(10) (2016) 1279-83.

[34] M. Davies, M. Nowotka, G. Papadatos, N. Dedman, A. Gaulton, F. Atkinson, L. Bellis, J.P. Overington, ChEMBL web services: streamlining access to drug discovery data and utilities, Nucleic Acids Res 43(W1) (2015) W612-20.

[35] J. Viana, E. Hannon, E. Dempster, R. Pidsley, R. Macdonald, O. Knox, H. Spiers, C. Troakes, S. Al-Saraj, G. Turecki, L.C. Schalkwyk, J. Mill, Schizophrenia-associated methylomic variation: molecular signatures of disease and polygenic risk burden across multiple brain regions, Hum Mol Genet 26(1) (2017) 210225.

[36] C.T. Watson, P. Roussos, P. Garg, D.J. Ho, N. Azam, P.L. Katsel, V. Haroutunian, A.J. Sharp, Genomewide DNA methylation profiling in the superior temporal gyrus reveals epigenetic signatures associated with Alzheimer's disease, Genome Med 8(1) (2016) 5.

[37] K.M. Bakulski, D.C. Dolinoy, M.A. Sartor, H.L. Paulson, J.R. Konen, A.P. Lieberman, R.L. Albin, H. Hu, L.S. Rozek, Genome-wide DNA methylation differences between late-onset Alzheimer's disease and cognitively normal controls in human frontal cortex, J Alzheimers Dis 29(3) (2012) 571-88.

[38] J.P. Reddington, S.M. Perricone, C.E. Nestor, J. Reichmann, N.A. Youngson, M. Suzuki, D. Reinhardt, D.S. Dunican, J.G. Prendergast, H. Mjoseng, B.H. Ramsahoye, E. Whitelaw, J.M. Greally, I.R. Adams, W.A. Bickmore, R.R. Meehan, Redistribution of H3K27me3 upon DNA hypomethylation results in derepression of Polycomb target genes, Genome Biol 14(3) (2013) R25.

[39] A.B. Brinkman, H. Gu, S.J. Bartels, Y. Zhang, F. Matarese, F. Simmer, H. Marks, C. Bock, A. Gnirke, A. Meissner, H.G. Stunnenberg, Sequential ChIP-bisulfite sequencing enables direct genome-scale investigation of chromatin and DNA methylation cross-talk, Genome Res 22(6) (2012) 1128-38. [40] GSEA/MSigDB Team, GSEA FAQ, 2020. https://software.broadinstitute.org/cancer/software/gsea/wiki/index.php/FAQ\#Why does GSEA use 
medRxiv preprint doi: https://doi.org/10.1101/2021.03.01.21252029; this version posted March 2, 2021. The copyright holder for this preprint (which was not certified by peer review) is the author/funder, who has granted medRxiv a license to display the preprint in perpetuity.

It is made available under a CC-BY-NC-ND 4.0 International license .

a false discovery rate 28 FDR.29 of 0.25 rather than the more classic 0.05.3F. (Accessed 24 Nov 2020).

[41] B. Zhang, C. Gaiteri, L.G. Bodea, Z. Wang, J. McElwee, A.A. Podtelezhnikov, C. Zhang, T. Xie, L. Tran, R. Dobrin, E. Fluder, B. Clurman, S. Melquist, M. Narayanan, C. Suver, H. Shah, M. Mahajan, T. Gillis, J. Mysore, M.E. MacDonald, J.R. Lamb, D.A. Bennett, C. Molony, D.J. Stone, V. Gudnason, A.J. Myers, E.E. Schadt, H. Neumann, J. Zhu, V. Emilsson, Integrated systems approach identifies genetic nodes and networks in late-onset Alzheimer's disease, Cell 153(3) (2013) 707-20.

[42] C. Cosarderelioglu, L.S. Nidadavolu, C.J. George, E.S. Oh, D.A. Bennett, J.D. Walston, P.M. Abadir, Brain Renin-Angiotensin System at the Intersect of Physical and Cognitive Frailty, Front Neurosci 14 (2020) 586314.

[43] A. Benigni, P. Cassis, G. Remuzzi, Angiotensin II revisited: new roles in inflammation, immunology and aging, EMBO Mol Med 2(7) (2010) 247-57.

[44] S. Manoharan, G.J. Guillemin, R.S. Abiramasundari, M.M. Essa, M. Akbar, M.D. Akbar, The Role of Reactive Oxygen Species in the Pathogenesis of Alzheimer's Disease, Parkinson's Disease, and Huntington's Disease: A Mini Review, Oxid Med Cell Longev 2016 (2016) 8590578.

[45] Y.Y. Chen, M.C. Wang, Y.N. Wang, H.H. Hu, Q.Q. Liu, H.J. Liu, Y.Y. Zhao, Redox signaling and Alzheimer's disease: from pathomechanism insights to biomarker discovery and therapy strategy, Biomark Res 8 (2020) 42.

[46] J. Rustenhoven, A.M. Smith, L.C. Smyth, D. Jansson, E.L. Scotter, M.E.V. Swanson, M. Aalderink, N. Coppieters, P. Narayan, R. Handley, C. Overall, T.I.H. Park, P. Schweder, P. Heppner, M.A. Curtis, R.L.M. Faull, M. Dragunow, PU.1 regulates Alzheimer's disease-associated genes in primary human microglia, Mol Neurodegener 13(1) (2018) 44.

[47] Y. Deming, L. Dumitrescu, L.L. Barnes, M. Thambisetty, B. Kunkle, K.A. Gifford, W.S. Bush, L.B. Chibnik, S. Mukherjee, P.L. De Jager, W. Kukull, M. Huentelman, P.K. Crane, S.M. Resnick, C.D. Keene, T.J. Montine, G.D. Schellenberg, J.L. Haines, H. Zetterberg, K. Blennow, E.B. Larson, S.C. Johnson, M. Albert, A. Moghekar, J.L. Del Aguila, M.V. Fernandez, J. Budde, J. Hassenstab, A.M. Fagan, M. Riemenschneider, R.C. Petersen, L. Minthon, M.J. Chao, V.M. Van Deerlin, V.M. Lee, L.M. Shaw, J.Q. Trojanowski, E.R. Peskind, G. Li, L.K. Davis, J.M. Sealock, N.J. Cox, I. Alzheimer's Disease Neuroimaging, C. Alzheimer Disease Genetics, A.M. Goate, D.A. Bennett, J.A. Schneider, A.L. Jefferson, C. Cruchaga, T.J. Hohman, Sex-specific genetic predictors of Alzheimer's disease biomarkers, Acta Neuropathol 136(6) (2018) 857872.

[48] L. Dumitrescu, L.L. Barnes, M. Thambisetty, G. Beecham, B. Kunkle, W.S. Bush, K.A. Gifford, L.B. Chibnik, S. Mukherjee, P.L. De Jager, W. Kukull, P.K. Crane, S.M. Resnick, C.D. Keene, T.J. Montine, G.D. Schellenberg, Y. Deming, M.J. Chao, M. Huentelman, E.R. Martin, K. Hamilton-Nelson, L.M. Shaw, J.Q. Trojanowski, E.R. Peskind, C. Cruchaga, M.A. Pericak-Vance, A.M. Goate, N.J. Cox, J.L. Haines, H. Zetterberg, K. Blennow, E.B. Larson, S.C. Johnson, M. Albert, C. Alzheimer's Disease Genetics, I. the Alzheimer's Disease Neuroimaging, D.A. Bennett, J.A. Schneider, A.L. Jefferson, T.J. Hohman, Sex differences in the genetic predictors of Alzheimer's pathology, Brain 142(9) (2019) 2581-2589.

[49] R. Scacchi, G. Gambina, E. Broggio, R.M. Corbo, Sex and ESR1 genotype may influence the response to treatment with donepezil and rivastigmine in patients with Alzheimer's disease, Int J Geriatr Psychiatry 29(6) (2014) 610-5.

[50] M. Shimabukuro, Y. Jinno, C. Fuke, Y. Okazaki, Haloperidol treatment induces tissue- and sexspecific changes in DNA methylation: a control study using rats, Behav Brain Funct 2 (2006) 37.

[51] M. Shimabukuro, T. Sasaki, A. Imamura, T. Tsujita, C. Fuke, T. Umekage, M. Tochigi, K. Hiramatsu, T. Miyazaki, T. Oda, J. Sugimoto, Y. Jinno, Y. Okazaki, Global hypomethylation of peripheral leukocyte DNA in male patients with schizophrenia: a potential link between epigenetics and schizophrenia, J Psychiatr Res 41(12) (2007) 1042-6. 
medRxiv preprint doi: https://doi.org/10.1101/2021.03.01.21252029; this version posted March 2, 2021. The copyright holder for this preprint (which was not certified by peer review) is the author/funder, who has granted medRxiv a license to display the preprint in perpetuity.

It is made available under a CC-BY-NC-ND 4.0 International license .

[52] M. Ibarra, M. Vazquez, P. Fagiolino, H. Derendorf, Sex related differences on valproic acid pharmacokinetics after oral single dose, J Pharmacokinet Pharmacodyn 40(4) (2013) 479-86.

[53] ClinicalTrials.gov., Drug Interaction Study With a Potential Alzheimer's Disease Compound. https://clinicaltrials.gov/ct2/show/NCT00726726?id=\%22NCT00692510\%220R\%22NCT00726726\%22\&d raw=2\&rank=1. (Accessed 31 Jan 2021).

[54] ClinicalTrials.gov., Drug Interaction Study Between AZD3480 and Cytochrome P450 (Cocktail). https://clinicaltrials.gov/ct2/show/NCT00692510?id=\%22NCT00692510\%220R\%22NCT00726726\%22\&d raw=2\&rank=2. (Accessed 31 Jan 2021).

[55] I. Driscoll, S.A. Shumaker, B.M. Snively, K.L. Margolis, J.E. Manson, M.Z. Vitolins, R.C. Rossom, M.A. Espeland, Relationships Between Caffeine Intake and Risk for Probable Dementia or Global Cognitive Impairment: The Women's Health Initiative Memory Study, J Gerontol A Biol Sci Med Sci 71(12) (2016) 1596-1602.

[56] J.W. Kim, M.S. Byun, D. Yi, J.H. Lee, S.Y. Jeon, G. Jung, H.N. Lee, B.K. Sohn, J.Y. Lee, Y.K. Kim, S.A. Shin, C.H. Sohn, D.Y. Lee, K.R. Group, Coffee intake and decreased amyloid pathology in human brain, Transl Psychiatry 9(1) (2019) 270.

[57] H.J. Jee, S.G. Lee, K.J. Bormate, Y.S. Jung, Effect of Caffeine Consumption on the Risk for Neurological and Psychiatric Disorders: Sex Differences in Human, Nutrients 12(10) (2020).

[58] S.I. Alfonso, J.A. Callender, B. Hooli, C.E. Antal, K. Mullin, M.A. Sherman, S.E. Lesne, M. Leitges, A.C. Newton, R.E. Tanzi, R. Malinow, Gain-of-function mutations in protein kinase Calpha (PKCalpha) may promote synaptic defects in Alzheimer's disease, Sci Signal 9(427) (2016) ra47.

[59] A. John, P.H. Reddy, Synaptic basis of Alzheimer's disease: Focus on synaptic amyloid beta, P-tau and mitochondria, Ageing Res Rev 65 (2020) 101208.

[60] C.A. Saura, J. Valero, The role of CREB signaling in Alzheimer's disease and other cognitive disorders, Rev Neurosci 22(2) (2011) 153-69.

[61] S.T. DeKosky, S.W. Scheff, Synapse loss in frontal cortex biopsies in Alzheimer's disease: correlation with cognitive severity, Ann Neurol 27(5) (1990) 457-64.

[62] R.D. Terry, E. Masliah, D.P. Salmon, N. Butters, R. DeTeresa, R. Hill, L.A. Hansen, R. Katzman, Physical basis of cognitive alterations in Alzheimer's disease: synapse loss is the major correlate of cognitive impairment, Ann Neurol 30(4) (1991) 572-80.

[63] E. Masliah, M. Mallory, M. Alford, R. DeTeresa, L.A. Hansen, D.W. McKeel, Jr., J.C. Morris, Altered expression of synaptic proteins occurs early during progression of Alzheimer's disease, Neurology 56(1) (2001) 127-9.

[64] S.W. Scheff, D.A. Price, F.A. Schmitt, S.T. DeKosky, E.J. Mufson, Synaptic alterations in CA1 in mild Alzheimer disease and mild cognitive impairment, Neurology 68(18) (2007) 1501-8.

[65] C. International Multiple Sclerosis Genetics, Comprehensive follow-up of the first genome-wide association study of multiple sclerosis identifies KIF21B and TMEM39A as susceptibility loci, Hum Mol Genet 19(5) (2010) 953-62.

[66] J. Varade, M. Comabella, M.A. Ortiz, R. Arroyo, O. Fernandez, M.J. Pinto-Medel, M. Fedetz, G. Izquierdo, M. Lucas, C.L. Gomez, A.C. Rabasa, A. Alcina, F. Matesanz, I. Alloza, A. Antiguedad, M. GarciaBarcina, D. Otaegui, J. Olascoaga, A. Saiz, Y. Blanco, X. Montalban, K. Vandenbroeck, E. Urcelay, Replication study of 10 genes showing evidence for association with multiple sclerosis: validation of TMEM39A, IL12B and CBLB [correction of CLBL] genes, Mult Scler 18(7) (2012) 959-65.

[67] Q. Tran, J. Park, H. Lee, Y. Hong, S. Hong, S. Park, J. Park, S.H. Kim, TMEM39A and Human Diseases: A Brief Review, Toxicol Res 33(3) (2017) 205-209.

[68] M. Ferrer-Ferrer, A. Dityatev, Shaping Synapses by the Neural Extracellular Matrix, Front Neuroanat 12 (2018) 40.

[69] B.W. Kunkle, B. Grenier-Boley, R. Sims, J.C. Bis, V. Damotte, A.C. Naj, A. Boland, M. Vronskaya, S.J. van der Lee, A. Amlie-Wolf, C. Bellenguez, A. Frizatti, V. Chouraki, E.R. Martin, K. Sleegers, N. 
medRxiv preprint doi: https://doi.org/10.1101/2021.03.01.21252029; this version posted March 2, 2021. The copyright holder for this preprint (which was not certified by peer review) is the author/funder, who has granted medRxiv a license to display the preprint in perpetuity. It is made available under a CC-BY-NC-ND 4.0 International license .

Badarinarayan, J. Jakobsdottir, K.L. Hamilton-Nelson, S. Moreno-Grau, R. Olaso, R. Raybould, Y. Chen, A.B. Kuzma, M. Hiltunen, T. Morgan, S. Ahmad, B.N. Vardarajan, J. Epelbaum, P. Hoffmann, M. Boada, G.W. Beecham, J.G. Garnier, D. Harold, A.L. Fitzpatrick, O. Valladares, M.L. Moutet, A. Gerrish, A.V. Smith, L. Qu, D. Bacq, N. Denning, X. Jian, Y. Zhao, M. Del Zompo, N.C. Fox, S.H. Choi, I. Mateo, J.T. Hughes, H.H. Adams, J. Malamon, F. Sanchez-Garcia, Y. Patel, J.A. Brody, B.A. Dombroski, M.C.D. Naranjo, M. Daniilidou, G. Eiriksdottir, S. Mukherjee, D. Wallon, J. Uphill, T. Aspelund, L.B. Cantwell, F. Garzia, D. Galimberti, E. Hofer, M. Butkiewicz, B. Fin, E. Scarpini, C. Sarnowski, W.S. Bush, S. Meslage, J. Kornhuber, C.C. White, Y. Song, R.C. Barber, S. Engelborghs, S. Sordon, D. Voijnovic, P.M. Adams, R. Vandenberghe, M. Mayhaus, L.A. Cupples, M.S. Albert, P.P. De Deyn, W. Gu, J.J. Himali, D. Beekly, A. Squassina, A.M. Hartmann, A. Orellana, D. Blacker, E. Rodriguez-Rodriguez, S. Lovestone, M.E. Garcia, R.S. Doody, C. Munoz-Fernadez, R. Sussams, H. Lin, T.J. Fairchild, Y.A. Benito, C. Holmes, H. KaramujicComic, M.P. Frosch, H. Thonberg, W. Maier, G. Roshchupkin, B. Ghetti, V. Giedraitis, A. Kawalia, S. Li, R.M. Huebinger, L. Kilander, S. Moebus, I. Hernandez, M.I. Kamboh, R. Brundin, J. Turton, Q. Yang, M.J. Katz, L. Concari, J. Lord, A.S. Beiser, C.D. Keene, S. Helisalmi, I. Kloszewska, W.A. Kukull, A.M. Koivisto, A. Lynch, L. Tarraga, E.B. Larson, A. Haapasalo, B. Lawlor, T.H. Mosley, R.B. Lipton, V. Solfrizzi, M. Gill, W.T. Longstreth, Jr., T.J. Montine, V. Frisardi, M. Diez-Fairen, F. Rivadeneira, R.C. Petersen, V. Deramecourt, I. Alvarez, F. Salani, A. Ciaramella, E. Boerwinkle, E.M. Reiman, N. Fievet, J.I. Rotter, J.S. Reisch, O. Hanon, C. Cupidi, A.G. Andre Uitterlinden, D.R. Royall, C. Dufouil, R.G. Maletta, I. de Rojas, M. Sano, A. Brice, R. Cecchetti, P.S. George-Hyslop, K. Ritchie, M. Tsolaki, D.W. Tsuang, B. Dubois, D. Craig, C.K. Wu, H. Soininen, D. Avramidou, R.L. Albin, L. Fratiglioni, A. Germanou, L.G. Apostolova, L. Keller, M. Koutroumani, S.E. Arnold, F. Panza, O. Gkatzima, S. Asthana, D. Hannequin, P. Whitehead, C.S. Atwood, P. Caffarra, H. Hampel, I. Quintela, A. Carracedo, L. Lannfelt, D.C. Rubinsztein, L.L. Barnes, F. Pasquier, L. Frolich, S. Barral, B. McGuinness, T.G. Beach, J.A. Johnston, J.T. Becker, P. Passmore, E.H. Bigio, J.M. Schott, T.D. Bird, J.D. Warren, B.F. Boeve, M.K. Lupton, J.D. Bowen, P. Proitsi, A. Boxer, J.F. Powell, J.R. Burke, J.S.K. Kauwe, J.M. Burns, M. Mancuso, J.D. Buxbaum, U. Bonuccelli, N.J. Cairns, A. McQuillin, C. Cao, G. Livingston, C.S. Carlson, N.J. Bass, C.M. Carlsson, J. Hardy, R.M. Carney, J. Bras, M.M. Carrasquillo, R. Guerreiro, M. Allen, H.C. Chui, E. Fisher, C. Masullo, E.A. Crocco, C. DeCarli, G. Bisceglio, M. Dick, L. Ma, R. Duara, N.R. Graff-Radford, D.A. Evans, A. Hodges, K.M. Faber, M. Scherer, K.B. Fallon, M. Riemenschneider, D.W. Fardo, R. Heun, M.R. Farlow, H. Kolsch, S. Ferris, M. Leber, T.M. Foroud, I. Heuser, D.R. Galasko, I. Giegling, M. Gearing, M. Hull, D.H. Geschwind, J.R. Gilbert, J. Morris, R.C. Green, K. Mayo, J.H. Growdon, T. Feulner, R.L. Hamilton, L.E. Harrell, D. Drichel, L.S. Honig, T.D. Cushion, M.J. Huentelman, P. Hollingworth, C.M. Hulette, B.T. Hyman, R. Marshall, G.P. Jarvik, A. Meggy, E. Abner, G.E. Menzies, L.W. Jin, G. Leonenko, L.M. Real, G.R. Jun, C.T. Baldwin, D. Grozeva, A. Karydas, G. Russo, J.A. Kaye, R. Kim, F. Jessen, N.W. Kowall, B. Vellas, J.H. Kramer, E. Vardy, F.M. LaFerla, K.H. Jockel, J.J. Lah, M. Dichgans, J.B. Leverenz, D. Mann, A.I. Levey, S. Pickering-Brown, A.P. Lieberman, N. Klopp, K.L. Lunetta, H.E. Wichmann, C.G. Lyketsos, K. Morgan, D.C. Marson, K. Brown, F. Martiniuk, C. Medway, D.C. Mash, M.M. Nothen, E. Masliah, N.M. Hooper, W.C. McCormick, A. Daniele, S.M. McCurry, A. Bayer, A.N. McDavid, J. Gallacher, A.C. McKee, H. van den Bussche, M. Mesulam, C. Brayne, B.L. Miller, S. RiedelHeller, C.A. Miller, J.W. Miller, A. Al-Chalabi, J.C. Morris, C.E. Shaw, A.J. Myers, J. Wiltfang, S. O'Bryant, J.M. Olichney, V. Alvarez, J.E. Parisi, A.B. Singleton, H.L. Paulson, J. Collinge, W.R. Perry, S. Mead, E. Peskind, D.H. Cribbs, M. Rossor, A. Pierce, N.S. Ryan, W.W. Poon, B. Nacmias, H. Potter, S. Sorbi, J.F. Quinn, E. Sacchinelli, A. Raj, G. Spalletta, M. Raskind, C. Caltagirone, P. Bossu, M.D. Orfei, B. Reisberg, R. Clarke, C. Reitz, A.D. Smith, J.M. Ringman, D. Warden, E.D. Roberson, G. Wilcock, E. Rogaeva, A.C. Bruni, H.J. Rosen, M. Gallo, R.N. Rosenberg, Y. Ben-Shlomo, M.A. Sager, P. Mecocci, A.J. Saykin, P. Pastor, M.L. Cuccaro, J.M. Vance, J.A. Schneider, L.S. Schneider, S. Slifer, W.W. Seeley, A.G. Smith, J.A. Sonnen, S. Spina, R.A. Stern, R.H. Swerdlow, M. Tang, R.E. Tanzi, J.Q. Trojanowski, J.C. Troncoso, V.M. Van Deerlin, L.J. Van Eldik, H.V. Vinters, J.P. Vonsattel, S. Weintraub, K.A. Welsh-Bohmer, K.C. Wilhelmsen, J. Williamson, T.S. Wingo, R.L. Woltjer, C.B. Wright, C.E. Yu, L. Yu, Y. Saba, A. Pilotto, M.J. Bullido, O. Peters, 
medRxiv preprint doi: https://doi.org/10.1101/2021.03.01.21252029; this version posted March 2, 2021. The copyright holder for this preprint (which was not certified by peer review) is the author/funder, who has granted medRxiv a license to display the preprint in perpetuity. It is made available under a CC-BY-NC-ND 4.0 International license .

P.K. Crane, D. Bennett, P. Bosco, E. Coto, V. Boccardi, P.L. De Jager, A. Lleo, N. Warner, O.L. Lopez, M. Ingelsson, P. Deloukas, C. Cruchaga, C. Graff, R. Gwilliam, M. Fornage, A.M. Goate, P. Sanchez-Juan, P.G. Kehoe, N. Amin, N. Ertekin-Taner, C. Berr, S. Debette, S. Love, L.J. Launer, S.G. Younkin, J.F. Dartigues, C. Corcoran, M.A. Ikram, D.W. Dickson, G. Nicolas, D. Campion, J. Tschanz, H. Schmidt, H. Hakonarson, J. Clarimon, R. Munger, R. Schmidt, L.A. Farrer, C. Van Broeckhoven, C.O.D. M, A.L. DeStefano, L. Jones, J.L. Haines, J.F. Deleuze, M.J. Owen, V. Gudnason, R. Mayeux, V. Escott-Price, B.M. Psaty, A. Ramirez, L.S. Wang, A. Ruiz, C.M. van Duijn, P.A. Holmans, S. Seshadri, J. Williams, P. Amouyel, G.D. Schellenberg, J.C. Lambert, M.A. Pericak-Vance, C. Alzheimer Disease Genetics, I. European Alzheimer's Disease, H.

Cohorts for, C. Aging Research in Genomic Epidemiology, Genetic, P. Environmental Risk in Ad/Defining Genetic, C. Environmental Risk for Alzheimer's Disease, Genetic meta-analysis of diagnosed Alzheimer's disease identifies new risk loci and implicates Abeta, tau, immunity and lipid processing, Nature genetics 51(3) (2019) 414-430.

[70] A. Ramasamy, D. Trabzuni, S. Guelfi, V. Varghese, C. Smith, R. Walker, T. De, U.K.B.E. Consortium, C. North American Brain Expression, L. Coin, R. de Silva, M.R. Cookson, A.B. Singleton, J. Hardy, M. Ryten, M.E. Weale, Genetic variability in the regulation of gene expression in ten regions of the human brain, Nat Neurosci 17(10) (2014) 1418-1428.

[71] H. Spiers, E. Hannon, L.C. Schalkwyk, R. Smith, C.C. Wong, M.C. O'Donovan, N.J. Bray, J. Mill, Methylomic trajectories across human fetal brain development, Genome Res 25(3) (2015) 338-52.

[72] K.A. Perzel Mandell, A.J. Price, R. Wilton, L. Collado-Torres, R. Tao, N.J. Eagles, A.S. Szalay, T.M. Hyde, D.R. Weinberger, J.E. Kleinman, A.E. Jaffe, Characterizing the dynamic and functional DNA methylation landscape in the developing human cortex, Epigenetics (2020) 1-13.

[73] J. Ma, T. Jiang, L. Tan, J.T. Yu, TYROBP in Alzheimer's disease, Mol Neurobiol 51(2) (2015) 820-6.

[74] C. Pottier, T.A. Ravenscroft, P.H. Brown, N.A. Finch, M. Baker, M. Parsons, Y.W. Asmann, Y. Ren, E. Christopher, D. Levitch, M. van Blitterswijk, C. Cruchaga, D. Campion, G. Nicolas, A.C. Richard, R. Guerreiro, J.T. Bras, S. Zuchner, M.A. Gonzalez, G. Bu, S. Younkin, D.S. Knopman, K.A. Josephs, J.E. Parisi, R.C. Petersen, N. Ertekin-Taner, N.R. Graff-Radford, B.F. Boeve, D.W. Dickson, R. Rademakers, TYROBP genetic variants in early-onset Alzheimer's disease, Neurobiol Aging 48 (2016) 222 e9-222 e15.

[75] J. Paloneva, T. Manninen, G. Christman, K. Hovanes, J. Mandelin, R. Adolfsson, M. Bianchin, T. Bird, R. Miranda, A. Salmaggi, L. Tranebjaerg, Y. Konttinen, L. Peltonen, Mutations in two genes encoding different subunits of a receptor signaling complex result in an identical disease phenotype, Am J Hum Genet 71(3) (2002) 656-62.

[76] K.L. Huang, E. Marcora, A.A. Pimenova, A.F. Di Narzo, M. Kapoor, S.C. Jin, O. Harari, S. Bertelsen, B.P. Fairfax, J. Czajkowski, V. Chouraki, B. Grenier-Boley, C. Bellenguez, Y. Deming, A. McKenzie, T. Raj, A.E. Renton, J. Budde, A. Smith, A. Fitzpatrick, J.C. Bis, A. DeStefano, H.H.H. Adams, M.A. Ikram, S. van der Lee, J.L. Del-Aguila, M.V. Fernandez, L. Ibanez, P. International Genomics of Alzheimer's, I. Alzheimer's Disease Neuroimaging, R. Sims, V. Escott-Price, R. Mayeux, J.L. Haines, L.A. Farrer, M.A. Pericak-Vance, J.C. Lambert, C. van Duijn, L. Launer, S. Seshadri, J. Williams, P. Amouyel, G.D. Schellenberg, B. Zhang, I. Borecki, J.S.K. Kauwe, C. Cruchaga, K. Hao, A.M. Goate, A common haplotype lowers PU.1 expression in myeloid cells and delays onset of Alzheimer's disease, Nat Neurosci 20(8) (2017) 1052-1061.

[77] G. Sessa, P. Podini, M. Mariani, A. Meroni, R. Spreafico, F. Sinigaglia, M. Colonna, P. Panina, J. Meldolesi, Distribution and signaling of TREM2/DAP12, the receptor system mutated in human polycystic lipomembraneous osteodysplasia with sclerosing leukoencephalopathy dementia, Eur J Neurosci 20(10) (2004) 2617-28.

[78] M. Bjorkqvist, M. Ohlsson, L. Minthon, O. Hansson, Evaluation of a previously suggested plasma biomarker panel to identify Alzheimer's disease, PLoS One 7(1) (2012) e29868.

[79] S. Ray, M. Britschgi, C. Herbert, Y. Takeda-Uchimura, A. Boxer, K. Blennow, L.F. Friedman, D.R. Galasko, M. Jutel, A. Karydas, J.A. Kaye, J. Leszek, B.L. Miller, L. Minthon, J.F. Quinn, G.D. Rabinovici, 
medRxiv preprint doi: https://doi.org/10.1101/2021.03.01.21252029; this version posted March 2, 2021. The copyright holder for this preprint (which was not certified by peer review) is the author/funder, who has granted medRxiv a license to display the preprint in perpetuity.

It is made available under a CC-BY-NC-ND 4.0 International license .

W.H. Robinson, M.N. Sabbagh, Y.T. So, D.L. Sparks, M. Tabaton, J. Tinklenberg, J.A. Yesavage, R. Tibshirani, T. Wyss-Coray, Classification and prediction of clinical Alzheimer's diagnosis based on plasma signaling proteins, Nat Med 13(11) (2007) 1359-62.

[80] B.P. Morgan, Complement in the pathogenesis of Alzheimer's disease, Semin Immunopathol 40(1) (2018) 113-124.

[81] L. Olsen, H.B. Rasmussen, T. Hansen, Y.Z. Bagger, L.B. Tanko, G. Qin, C. Christiansen, T. Werge, Estrogen receptor alpha and risk for cognitive impairment in postmenopausal women, Psychiatr Genet 16(2) (2006) 85-8.

[82] K. Yaffe, L.Y. Lui, D. Grady, K. Stone, P. Morin, Estrogen receptor 1 polymorphisms and risk of cognitive impairment in older women, Biol Psychiatry 51(8) (2002) 677-82.

[83] M. Boada, C. Antunez, J. Lopez-Arrieta, A. Caruz, C. Moreno-Rey, R. Ramirez-Lorca, F.J. Moron, I. Hernandez, A. Mauleon, M. Rosende-Roca, P. Martinez-Lage, J. Marin, L. Tarraga, M. Alegret, J.R. Pedrajas, N. Urda, J.L. Royo, M.E. Saez, J. Gayan, A. Gonzalez-Perez, L.M. Real, A. Ruiz, J.J. Galan, Estrogen receptor alpha gene variants are associated with Alzheimer's disease, Neurobiol Aging 33(1) (2012) 198 e15-24.

[84] S.C. Janicki, N. Schupf, Hormonal influences on cognition and risk for Alzheimer's disease, Curr Neurol Neurosci Rep 10(5) (2010) 359-66.

[85] K. Yaffe, K. Lindquist, S. Sen, J. Cauley, R. Ferrell, B. Penninx, T. Harris, R. Li, S.R. Cummings, Estrogen receptor genotype and risk of cognitive impairment in elders: findings from the Health $A B C$ study, Neurobiol Aging 30(4) (2009) 607-14.

[86] R. Li, J. Cui, Y. Shen, Brain sex matters: estrogen in cognition and Alzheimer's disease, Mol Cell Endocrinol 389(1-2) (2014) 13-21.

[87] R.D. Brinton, Estrogen-induced plasticity from cells to circuits: predictions for cognitive function, Trends Pharmacol Sci 30(4) (2009) 212-22.

[88] S. Klein, A. Pekosz, C. Passaretti, M. Anker, P. Olukoya, Sex, Gender and Influenza World Health Organization (2010) 1-51.

[89] R.H. Straub, C. Schradin, Chronic inflammatory systemic diseases: An evolutionary trade-off between acutely beneficial but chronically harmful programs, Evol Med Public Health 2016(1) (2016) 3751.

[90] B.L. Peterson, S. Won, R.I. Geddes, I. Sayeed, D.G. Stein, Sex-related differences in effects of progesterone following neonatal hypoxic brain injury, Behav Brain Res 286 (2015) 152-65.

[91] R. Hanamsagar, S.D. Bilbo, Sex differences in neurodevelopmental and neurodegenerative disorders: Focus on microglial function and neuroinflammation during development, J Steroid Biochem Mol Biol 160 (2016) 127-33.

[92] M. Wennstrom, H.M. Nielsen, Cell adhesion molecules in Alzheimer's disease, Degener Neurol Neuromuscul Dis 2 (2012) 65-77.

[93] S. Sil, P. Periyasamy, A. Thangaraj, E.T. Chivero, S. Buch, PDGF/PDGFR axis in the neural systems, Mol Aspects Med 62 (2018) 63-74.

[94] N.K. Jha, S.K. Jha, R. Kar, P. Nand, K. Swati, V.K. Goswami, Nuclear factor-kappa beta as a therapeutic target for Alzheimer's disease, J Neurochem 150(2) (2019) 113-137.

[95] B. Qin, L. Li, S. Wang, J. Wu, Y. Huang, P. Zhou, J. Bai, Y. Zheng, Interleukin-8 gene polymorphism 251T>A contributes to Alzheimer's disease susceptibility, Medicine (Baltimore) 95(39) (2016) e5039.

[96] M. Bacher, O. Deuster, B. Aljabari, R. Egensperger, F. Neff, F. Jessen, J. Popp, C. Noelker, J.P. Reese, Y. Al-Abed, R. Dodel, The role of macrophage migration inhibitory factor in Alzheimer's disease, Mol Med 16(3-4) (2010) 116-21.

[97] B.L. Fiebich, C.R.A. Batista, S.W. Saliba, N.M. Yousif, A.C.P. de Oliveira, Role of Microglia TLRs in Neurodegeneration, Front Cell Neurosci 12 (2018) 329. 
medRxiv preprint doi: https://doi.org/10.1101/2021.03.01.21252029; this version posted March 2, 2021. The copyright holder for this preprint (which was not certified by peer review) is the author/funder, who has granted medRxiv a license to display the preprint in perpetuity.

It is made available under a CC-BY-NC-ND 4.0 International license.

[98] R. Chang, K.L. Yee, R.K. Sumbria, Tumor necrosis factor alpha Inhibition for Alzheimer's Disease, J Cent Nerv Syst Dis 9 (2017) 1179573517709278.

[99] U. Armato, B. Chakravarthy, R. Pacchiana, J.F. Whitfield, Alzheimer's disease: an update of the roles of receptors, astrocytes and primary cilia (review), Int J Mol Med 31(1) (2013) 3-10.

[100] K. Ono, M. Yamada, Vitamin A and Alzheimer's disease, Geriatr Gerontol Int 12(2) (2012) 180-8. [101] N.M. Kanaan, G.F. Pigino, S.T. Brady, O. Lazarov, L.I. Binder, G.A. Morfini, Axonal degeneration in Alzheimer's disease: when signaling abnormalities meet the axonal transport system, Exp Neurol 246 (2013) 44-53.

[102] S.T.T. Schetters, D. Gomez-Nicola, J.J. Garcia-Vallejo, Y. Van Kooyk, Neuroinflammation: Microglia and T Cells Get Ready to Tango, Front Immunol 8 (2017) 1905.

[103] M. Esposito, G.L. Sherr, Epigenetic Modifications in Alzheimer's Neuropathology and Therapeutics, Front Neurosci 13 (2019) 476.

[104] J.W. Griffin, P.C. Bradshaw, Amino Acid Catabolism in Alzheimer's Disease Brain: Friend or Foe?, Oxid Med Cell Longev 2017 (2017) 5472792.

[105] M.E. Conway, Alzheimer's disease: targeting the glutamatergic system, Biogerontology 21(3) (2020) 257-274. 

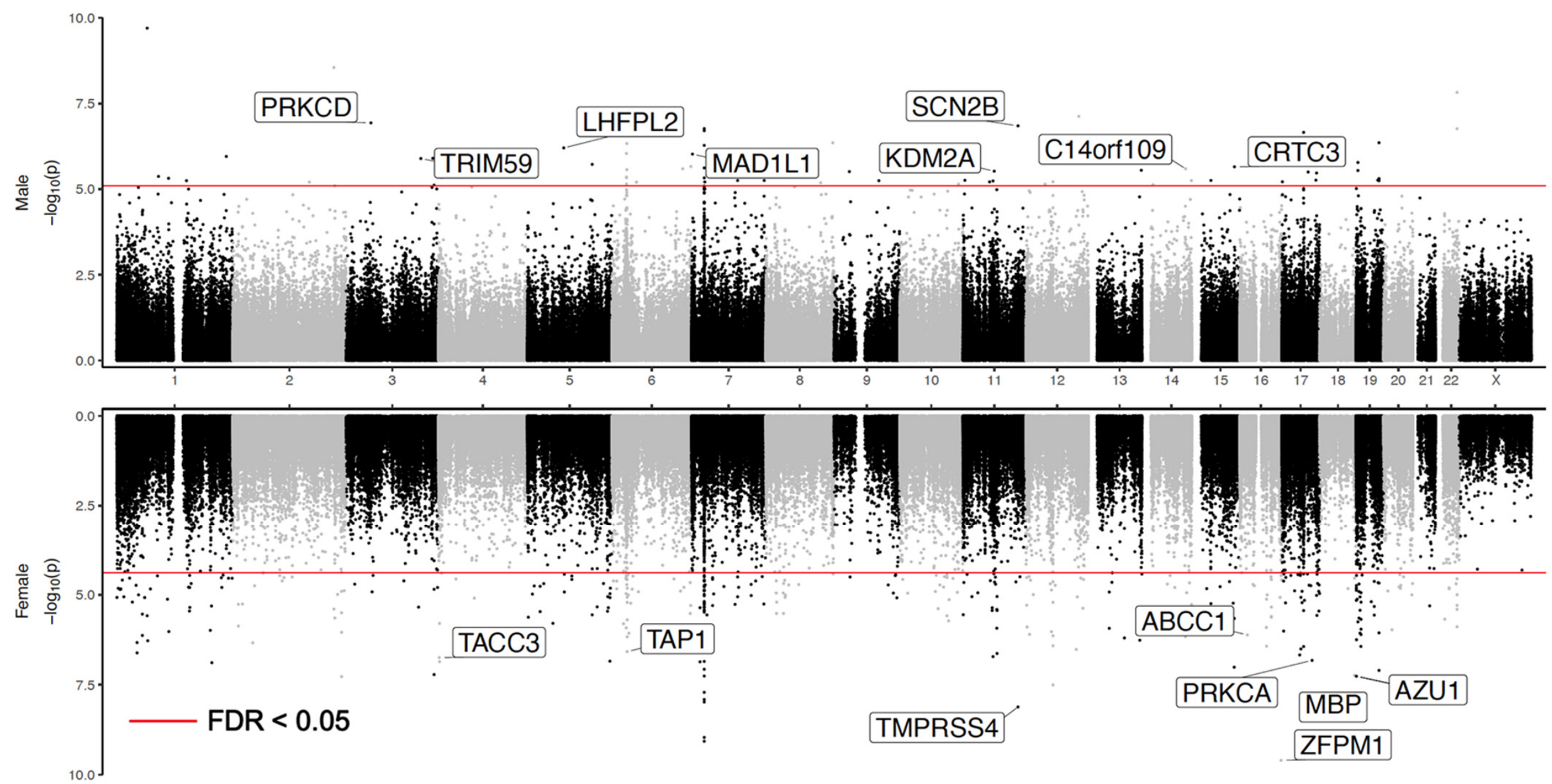

Figure 1 Miami plot of sex-stratified analysis results. The $X$-axis are chromosome numbers. The $Y$-axis show $-\log _{10}(\mathrm{P}$-value) of $\mathrm{CpG}$ - Braak stage associations in males (above $\mathrm{X}$-axis) or in females (below $\mathrm{X}$-axis). The genes corresponding to top $10 \mathrm{CpGs}$ that are the most significant in one sex (FDR $<0.05)$, but not significant in another sex ( $P$-value $>0.05)$ are highlighted. 


\section{Sex-specific DNA methylation changes in Alzheimer's disease pathology}

Lanyu Zhang ${ }^{1}$, Juan I. Young ${ }^{2,3}$, Lissette Gomez ${ }^{3}$, Tiago C. Silva ${ }^{1}$, Michael A. Schmidt ${ }^{2,3}$, Jesse Cai ${ }^{4}$, Xi Chen $^{1,5}$, Eden R. Martin ${ }^{2,3}$, Lily Wang ${ }^{1,2,3,5^{*}}$

${ }^{1}$ Division of Biostatistics, Department of Public Health Sciences, University of Miami, Miller School of Medicine, Miami, FL 33136, USA

${ }^{2}$ Dr. John T Macdonald Foundation Department of Human Genetics, University of Miami, Miller School of Medicine, Miami, FL 33136, USA

${ }^{3}$ John P. Hussman Institute for Human Genomics, University of Miami Miller School of Medicine, Miami, FL 33136, USA

${ }^{4}$ Brentwood High School, 5304 Murray Ln, Brentwood, TN 37027

${ }^{5}$ Sylvester Comprehensive Cancer Center, University of Miami, Miller School of Medicine, Miami, FL 33136, USA

* To whom correspondence should be addressed.

\section{Supplementary Text on Detailed Methods}

1. Pre-processing of DNA methylation data

2. Single cohort analysis

3. Inflation assessment and correction

4. Meta-analysis

5. Identifying sex-specific changes

6. Enrichment and pathway analysis

7. Integrative methylation - gene expression analysis

8. Sex-specific mQTL analysis 
medRxiv preprint doi: https://doi.org/10.1101/2021.03.01.21252029; this version posted March 2, 2021. The copyright holder for this preprint (which was not certified by peer review) is the author/funder, who has granted medRxiv a license to display the preprint in perpetuity. It is made available under a CC-BY-NC-ND 4.0 International license .

\section{Pre-processing of DNA methylation data}

Quality control for $\mathrm{CpG}$ probes included removing probes with detection P-value $<0.01$ in all samples of a cohort, those associated with cigarette smoking ${ }^{1}$, or those having a single nucleotide polymorphism (SNP) with minor allele frequency $(\mathrm{MAF}) \geq 0.01$ present in the last 5 base pairs of the probe. Quality control for samples included restricting our analysis to samples with good bisulfite conversion efficiency (i.e., $\geq 88 \%$ ) and principal component analysis (PCA). More specifically, PCA was performed using the 50,000 most variable $\mathrm{CpGs}$ for each cohort. Samples that were within \pm 3 standard deviations from the mean of PC1 and PC2 were selected to be included in the final sample set. The quality controlled methylation datasets were next subjected to the QN.BMIQ normalization procedure ${ }^{2}$ as previously described ${ }^{3}$. The recorded sex status of all samples matched those predicted based on methylation levels using getSex function in $\mathrm{R}$ package minfi. We removed batch effects by applying linear model methylation $\mathrm{M}$ value $\sim$ methylation slide. For the ROSMAP cohort, we additionally included the variable "batch" that was available in the dataset to adjust for technical batches which occurred during data generation. The residuals (methylation residuals) estimated from this model were then used for subsequent analyses.

\section{Single cohort analysis}

To identify sex-specific DNA methylation changes in AD, we performed both a sex-stratified analysis and a sex-by-Braak stage interaction analysis for each of the four brain sample cohorts. In sex-stratified analysis, we tested methylation-Braak stage associations in female and male samples separately. In sex-by-Braak stage interaction analysis, we analyzed both female and male samples simultaneously and compared slopes for methylation-Braak stage associations in females and males.

In sex-stratified analysis, for each $\mathrm{CpG}$, we applied the model methylation residuals age at death + Braak stage + $\mathrm{CETS}^{4}$ estimated neuron proportions to female samples and male samples separately. In sex-byBraak stage interaction analysis, for each $\mathrm{CpG}$, we applied the model methylation residuals age at death + sex + Braak stage + sex*Braak stage + sex*age at death + CETS estimated neuron proportions to samples of both sexes.

For the analysis of differentially methylated regions (DMRs), we used the coMethDMR R package ${ }^{5}$ to analyze 40,010 pre-defined genomic regions on the Illumina 450k arrays and identify co-methylated DMRs associated with Braak stage. The pre-defined genomic regions are regions on the Illumina array covered with clusters of contiguous CpGs where the maximum separation between any two consecutive probes is 200 base pairs. First, coMethDMR selects co-methylated sub-regions within these pre-defined contiguous genomic regions. Next, we summarized methylation $M$ values within these co-methylated sub-regions using medians and tested them against AD Braak stage. The same linear models described for the analysis of CpGs were then applied to median value of each DMR.

\section{Inflation assessment and correction}

To assess inflation of the test statistics, we used quantile-quantile (QQ) plots of observed and expected distributions of P-values for each cohort. Because the conventional genomic inflation factor (lambda or $\lambda$ 
medRxiv preprint doi: https://doi.org/10.1101/2021.03.01.21252029; this version posted March 2, 2021. The copyright holder for this preprint (which was not certified by peer review) is the author/funder, who has granted medRxiv a license to display the preprint in perpetuity. It is made available under a CC-BY-NC-ND 4.0 International license .

used interchangeably below) is dependent on the expected number of true associations, and in a typical EWAS it is expected that small effects from many CpGs might be associated with the phenotype, Iterson et al. (2017) $)^{6}$ showed that the conventional genomic inflation factor would overestimate actual test-statistic inflation in EWAS. To estimate genomic inflations more accurately in EWAS, Iterson et al. (2017) ${ }^{6}$ developed a Bayesian method that estimates and corrects inflation in EWAS based on empirical null distributions, which is implemented in the Bioconductor package bacon. We estimated genomic inflation factors using both the conventional approach and the bacon method. In addition, we also applied the bacon method to single cohort analysis results to obtain inflation-corrected effect sizes, standard errors, and pvalues for each cohort.

\section{Meta-analysis}

The results of the bacon-corrected cohort-specific analysis were then combined using inverse-variance weighted meta-analysis models. The evidence for heterogeneity of study effects was tested using Cochran's Q statistic ${ }^{7}$. More specifically, the inverse-variance weighted fixed effects model was first applied to synthesize statistical significance from individual cohorts. Even though the fixed effects model for metaanalysis does not require the assumption of homogeneity ${ }^{8}$, for the regions with nominal evidence for heterogeneity (nominal $\mathrm{P}_{\text {heterogeneity }}<0.05$ ), we also applied random effects meta-analysis ${ }^{9}$ and assigned final meta-analysis P-value based on the random effects model. For each $\mathrm{CpG}$ (and for each DMR), we used the $\mathrm{R}$ package meta to obtain meta-analysis $\mathrm{p}$-values for sex-by-Braak stage interaction, as well as Braak stage effect in female samples and male samples separately in sex-stratified analysis.

\section{Identifying sex-specific changes}

In sex-stratified analysis, we selected significant CpGs (or DMRs) with FDR $<0.05$ in female samples or male samples separately. In sex-by-Braak stage interaction analysis, because the standard error of interaction effect sex $\times$ Braak stage is typically much larger than those for main Braak stage effects, the conventional approach for controlling false discovery rate often results in low power for discovering interaction effects ${ }^{10}$. Therefore, we used a stagewise analysis approach, previously proposed by van de Berge et al. $(2017)^{10}$, to help improve power in high-throughput experiments where multiple hypotheses are tested for each gene. More specifically, in the screening step, for each CpG (or DMR), we tested the global null hypothesis that there is methylation-Braak stage association in either male or female samples. Next, in the confirmation step, we considered three individual null hypotheses for each CpG (or DMR): (a) there is no methylation-Braak stage association in male samples; (b) there is no methylation-Braak stage association in female samples; and (c) the methylation-Braak stage associations in male samples and female samples are the same. For the CpGs (or DMRs) selected in the screening step, these three individual hypotheses were then tested while controlling family-wise error rate (FWER) as described in van de Berge et al. $(2017)^{10}$.

The stagewise analysis described above was implemented using the stageR package to identify CpGs (or DMRs) with significant differential methylation - Braak stage associations in females and males. In the screening step, we considered meta-analysis p-values for Braak stage in female samples and male samples (p.meta.female, p.meta.male), and used the minimum of these two meta-analysis p-values to represent 
medRxiv preprint doi: https://doi.org/10.1101/2021.03.01.21252029; this version posted March 2, 2021. The copyright holder for this preprint (which was not certified by peer review) is the author/funder, who has granted medRxiv a license to display the preprint in perpetuity. It is made available under a CC-BY-NC-ND 4.0 International license .

each $\mathrm{CpG}$ (or DMR). In the confirmation step, the parameter pConfirmation was defined using three pvalues for each $\mathrm{CpG}$ (or DMR): p.meta.female, p.meta.male, and p.meta.interaction (meta-analysis pvalue for sex $\times$ Braak stage).

\section{Enrichment and pathway analysis}

The probes on the Illumina 450k array are annotated according to their locations with respect to genes (TSS1500, TSS200, 5'UTR, 1stExon, gene body, 3'UTR, intergenic) or to CpG islands (island, shore, shelf, open sea). To understand the genomic context of sex-specific DNA methylation changes in AD, we compared the FDR significant methylation changes from sex-stratified analysis with different types of genomic features. As pathological AD-associated methylation changes can occur at both significant individual CpGs and significant DMRs, we considered the CpGs located at significant individual CpGs or within significant DMRs jointly in this analysis, by testing their over- and under-representation in different types of genomic features using Fisher's exact test. More specifically, the proportion of significant CpGs mapped to a particular type of genomic feature (e.g., $\mathrm{CpG}$ islands) (foreground) was compared to the proportion of $\mathrm{CpGs}$ on the array that mapped to the same type of genomic feature (background).

In addition, we used Fisher's test to assess enrichment of significant CpGs and DMRs in different chromatin states by comparing with the 15-chromatin state data for DLPFC tissue samples (E073) from the Roadmap Epigenomics Project ${ }^{11}$. Using combinations of histone modification marks, ChromHMM ${ }^{12}$ was previously used to annotate segments of the genome with different chromatin states (repressed, poised and active promoters, strong and weak enhancers, putative insulators, transcribed regions, and large-scale repressed and inactive domains), which were shown to vary across sex, tissue type, and developmental age ${ }^{13}$. Similarly, we tested enrichment of significant CpGs and DMRs in binding sites of transcription factors and chromatin proteins from the ENCODE project ${ }^{14}$ and CODEX database ${ }^{15}$ using the LOLA R package ${ }^{16}$.

Finally, we performed pathway analysis by comparing the genes with significant DNA methylation changes in $\mathrm{AD}$ (identified in sex-stratified analysis) with the canonical pathways and biological process GO terms in MSigDB using GSEA analysis ${ }^{17}$. First, we linked each $\mathrm{CpG}$ and each pre-defined genomic region tested in DMR analysis (see Section "2. Single cohort analysis" above) to genes by annotating them using the GREAT (Genomic Regions Enrichment of Annotations Tool) software ${ }^{18}$ (with default "Basal plus method"), which associates genomic regions to target genes. Next, we represented each gene by the smallest p-value if multiple CpGs or genomic regions are associated with them. To remove selection bias due to different numbers of $\mathrm{CpGs}$ or genomic regions associated with each gene (i.e., P-values from a gene with many CpGs or genomic regions linked to it are likely to be smaller than a gene with few linked CpGs or DMRs), we next fit a generalized additive model ${ }^{19}$ using the R package mgcv: $Y_{i} \sim f\left(\right.$ n. links $\left.s_{i}\right)$ where $Y_{i}$ is negative $\log$ (base 10) transformation of the P-value for gene $i$ in the analysis of female samples (or male samples), n.links $s_{i}$ is the number of CpGs or DMRs associated with gene $i$, and $f$ is a penalized spline function. We assumed gamma distribution for $Y_{i}$, as under the null hypothesis of no association, $Y_{i}$ follows the chi-square distribution (a special case of gamma distribution). The residuals from this model were estimated and used to generate a ranked gene list, which was then used as input for GSEA (in pre-ranked mode) to identify canonical pathways and gene ontology terms (MsigDB C2:CP and C5:BP collections of gene sets) enriched with significant methylation changes in female samples and male samples separately. 
medRxiv preprint doi: https://doi.org/10.1101/2021.03.01.21252029; this version posted March 2, 2021. The copyright holder for this preprint (which was not certified by peer review) is the author/funder, who has granted medRxiv a license to display the preprint in perpetuity. It is made available under a CC-BY-NC-ND 4.0 International license .

\section{Integrative methylation - gene expression analysis}

To systematically evaluate transcriptional changes near the sex-specific DNA methylation changes, we next performed integrative methylation - gene expression analysis using 529 (333 female and 196 male) samples from the ROSMAP study with matched DNA methylation and gene expression data. To this end, normalized FPKM (Fragments Per Kilobase of transcript per Million mapped reads) gene expression values for the ROSMAP study were downloaded from the AMP-AD Knowledge Portal (Synapse ID: syn3388564). First, we linked significant CpGs (or DMRs) to nearby genes using GREAT ${ }^{18}$, which associates genomic regions to regulatory domains of genes. Next, we removed confounding effects in DNA methylation data by fitting the model methylation $\mathrm{M}$ value neuron.proportion + batch + sample.plate + ageAtDeath and extracting residuals from this model; these are the methylation residuals. Similarly, we also removed potential confounding effects in RNA-seq data by fitting model $\log 2$ (normalized FPKM values +1 ) ageAtDeath + markers for cell types. The last term, "markers for cell types," included multiple covariate variables to adjust for the multiple types of cells in the brain samples. More specifically, we estimated expression levels of genes that are specific for the five main cell types present in the CNS: ENO2 for neurons, GFAP for astrocytes, CD68 for microglia, OLIG2 for oligodendrocytes, and CD34 for endothelial cells, and included these as variables in the above linear regression model, as was done in a previous large study of AD samples ${ }^{20}$. The residuals extracted from this model are the gene expression residuals.

Finally, for each gene expression and CpG (or DMR) pair, we then tested the association between gene expression residuals and methylation residuals using a linear model: gene expression residuals methylation residuals + Braak stage. For significant DMRs, this analysis was repeated, except that methylation $\mathrm{M}$ value was replaced with median methylation $\mathrm{M}$ value from multiple $\mathrm{CpGs}$ in the DMR.

\section{Sex-specific mQTL analysis}

To identify methylation quantitative trait loci (mQTLs) for the significant DMRs and CpGs, we tested associations between the methylation levels with nearby SNPs, using the ROSMAP study dataset, which had matched genotype data and DNA methylation data for 688 samples (434 females, 254 males). ROSMAP genotype data was downloaded from AMP-AD (syn3157325) and imputed to the Haplotype Reference Consortium r1.1 reference panel $^{21}$. The male samples and female samples were analyzed separately.

To reduce the number of tests, we focused on identifying cis mQTLs located within $500 \mathrm{~kb}$ from the start or end of the DMR (or position of the significant $\mathrm{CpG}$ ) ${ }^{22}$. We additionally required SNPs to (1) have minor allele frequency of at least $1 \%$, (2) be imputed with good certainty: information metric (info score) $\geq 0.4$, and (3) be associated with AD case-control status (as determined by clinical consensus diagnosis of cognitive status), after adjusting for age, batch, and the first 3 PCs estimated from genotype data, at nominal P-value less than 0.05. We then fit the linear model methylation residual $\sim$ SNP dosage + batch + PC1 + PC2 + PC3, where PC1, PC2, and PC3 are the first three PCs estimated from genotype data, to test the association between methylation residuals in CpGs and the imputed allele dosages for SNPs to identify mQTLs. The 
medRxiv preprint doi: https://doi.org/10.1101/2021.03.01.21252029; this version posted March 2, 2021. The copyright holder for this preprint (which was not certified by peer review) is the author/funder, who has granted medRxiv a license to display the preprint in perpetuity.

It is made available under a CC-BY-NC-ND 4.0 International license.

analysis for DMRs was the same except that we replaced methylation residual with median (methylation residuals) of all CpGs located within the DMR. 
medRxiv preprint doi: https://doi.org/10.1101/2021.03.01.21252029; this version posted March 2, 2021. The copyright holder for this preprint (which was not certified by peer review) is the author/funder, who has granted medRxiv a license to display the preprint in perpetuity.

It is made available under a CC-BY-NC-ND 4.0 International license .

\section{References}

1. Joehanes, R. et al. Epigenetic Signatures of Cigarette Smoking. Circ Cardiovasc Genet 9, 436-447 (2016).

2. Wang, T. et al. A systematic study of normalization methods for Infinium 450K methylation data using whole-genome bisulfite sequencing data. Epigenetics 10, 662-9 (2015).

3. Zhang, L. et al. Epigenome-wide meta-analysis of DNA methylation differences in prefrontal cortex implicates the immune processes in Alzheimer's disease. Nat Commun 11, 6114 (2020).

4. Guintivano, J., Aryee, M.J. \& Kaminsky, Z.A. A cell epigenotype specific model for the correction of brain cellular heterogeneity bias and its application to age, brain region and major depression. Epigenetics 8, 290-302 (2013).

5. Gomez, L. et al. coMethDMR: accurate identification of co-methylated and differentially methylated regions in epigenome-wide association studies with continuous phenotypes. Nucleic Acids Res 47, e98 (2019).

6. van Iterson, M., van Zwet, E.W., Consortium, B. \& Heijmans, B.T. Controlling bias and inflation in epigenome- and transcriptome-wide association studies using the empirical null distribution.

Genome Biol 18, 19 (2017).

7. Higgins, J.P. \& Thompson, S.G. Quantifying heterogeneity in a meta-analysis. Stat Med 21, 153958 (2002).

8. Rice K, Higgins J \& T, L. A re-evaluation of fixed effect(s) meta-analysis. J R Stat Soc A 181, 205-27 (2018).

9. Riley, R.D., Higgins, J.P. \& Deeks, J.J. Interpretation of random effects meta-analyses. BMJ 342, d549 (2011).

10. Van den Berge, K., Soneson, C., Robinson, M.D. \& Clement, L. stageR: a general stage-wise method for controlling the gene-level false discovery rate in differential expression and differential transcript usage. Genome Biol 18, 151 (2017).

11. Chadwick, L.H. The NIH Roadmap Epigenomics Program data resource. Epigenomics 4, 317-24 (2012).

12. Ernst, J. \& Kellis, M. ChromHMM: automating chromatin-state discovery and characterization. Nat Methods 9, 215-6 (2012).

13. Yen, A. \& Kellis, M. Systematic chromatin state comparison of epigenomes associated with diverse properties including sex and tissue type. Nat Commun 6, 7973 (2015).

14. Davis, C.A. et al. The Encyclopedia of DNA elements (ENCODE): data portal update. Nucleic Acids Res 46, D794-D801 (2018).

15. Sanchez-Castillo, M. et al. CODEX: a next-generation sequencing experiment database for the haematopoietic and embryonic stem cell communities. Nucleic Acids Res 43, D1117-23 (2015).

16. Sheffield, N.C. \& Bock, C. LOLA: enrichment analysis for genomic region sets and regulatory elements in R and Bioconductor. Bioinformatics 32, 587-9 (2016).

17. Subramanian, A. et al. Gene set enrichment analysis: a knowledge-based approach for interpreting genome-wide expression profiles. Proc Natl Acad Sci U S A 102, 15545-50 (2005).

18. McLean, C.Y. et al. GREAT improves functional interpretation of cis-regulatory regions. Nat Biotechnol 28, 495-501 (2010).

19. Wood, S.N. mgcv: GAMs and Generalized Ridge Regression for R. R News 1, 20-25 (2001).

20. De Jager, P.L. et al. Alzheimer's disease: early alterations in brain DNA methylation at ANK1, BIN1, RHBDF2 and other loci. Nat Neurosci 17, 1156-63 (2014).

21. McCarthy, S. et al. A reference panel of 64,976 haplotypes for genotype imputation. Nat Genet 48, 1279-83 (2016). 
medRxiv preprint doi: https://doi.org/10.1101/2021.03.01.21252029; this version posted March 2, 2021. The copyright holder for this preprint (which was not certified by peer review) is the author/funder, who has granted medRxiv a license to display the preprint in perpetuity. It is made available under a CC-BY-NC-ND 4.0 International license.

22. Hannon, E. et al. An integrated genetic-epigenetic analysis of schizophrenia: evidence for colocalization of genetic associations and differential DNA methylation. Genome Biol 17, 176 (2016). 
medRxiv preprint doi: https://doi.org/10.1101/2021.03.01.21252029; this version posted March 2, 2021. The copyright holder for this preprint (which was not certified by peer review) is the author/funder, who has granted medRxiv a license to display the preprint in perpetuity. It is made available under a CC-BY-NC-ND 4.0 International license.

Supplementary Figure 1 Quantile-quantile (QQ) plots of observed and expected distributions of p-values in Gasparoni, London, Mount Sinai, and ROSMAP cohorts. $\lambda$ is the genomic inflation factor, and $\lambda_{\text {bacon }}$ is the genomic inflation factor estimated using the method of Iterson et al. (2017) (PMID: 28129774), as implemented in the bacon $\mathrm{R}$ package. Shading indicates $95 \%$ confidence intervals. Reference line in red indicates expected distribution of $-\log _{10}$ (P-values) under the null hypothesis of no association.

(A) for analysis results of female samples
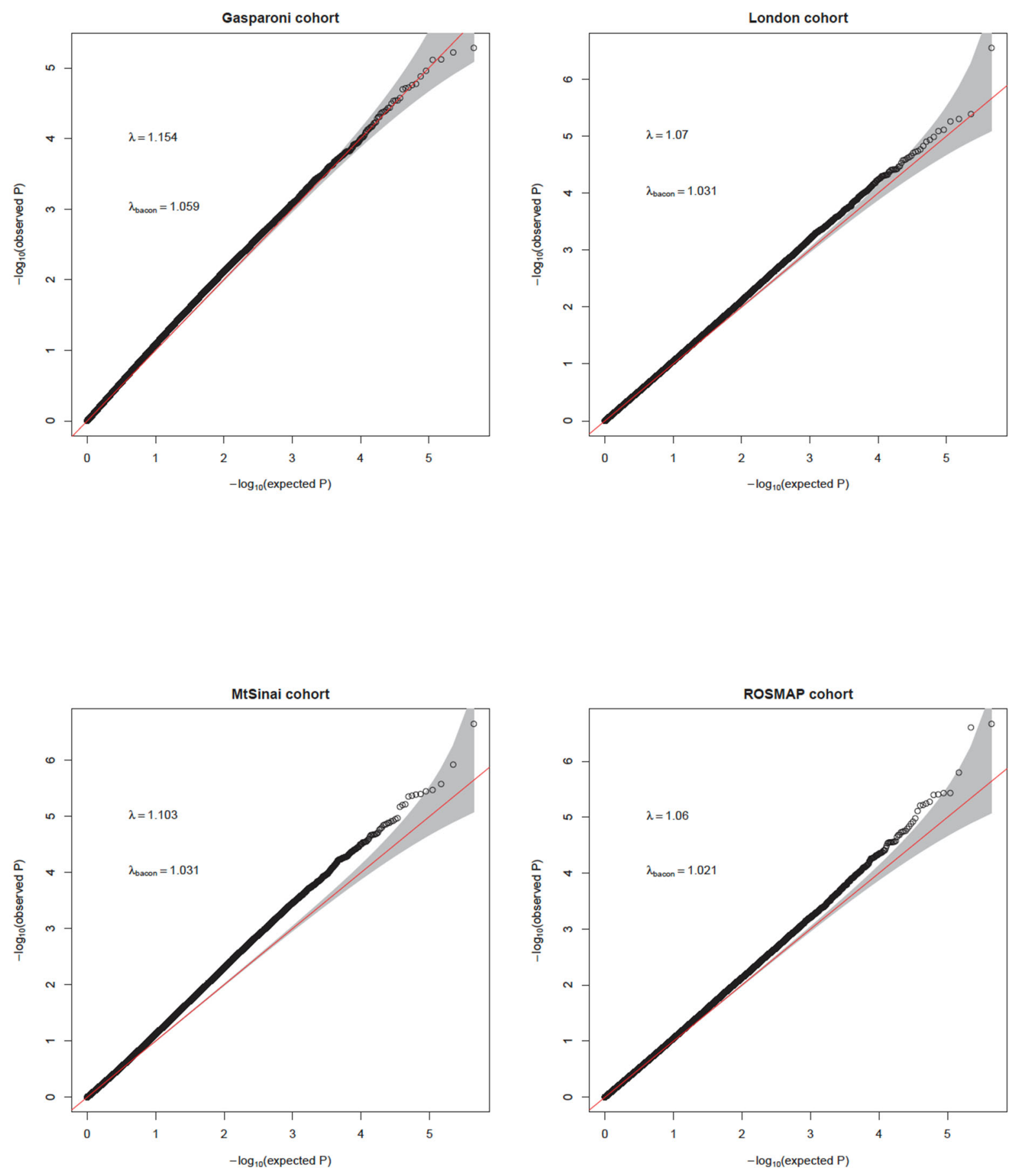
medRxiv preprint doi: https://doi.org/10.1101/2021.03.01.21252029; this version posted March 2, 2021. The copyright holder for this preprint (which was not certified by peer review) is the author/funder, who has granted medRxiv a license to display the preprint in perpetuity.

\section{It is made available under a CC-BY-NC-ND 4.0 International license .}

(B) for analysis results of male samples
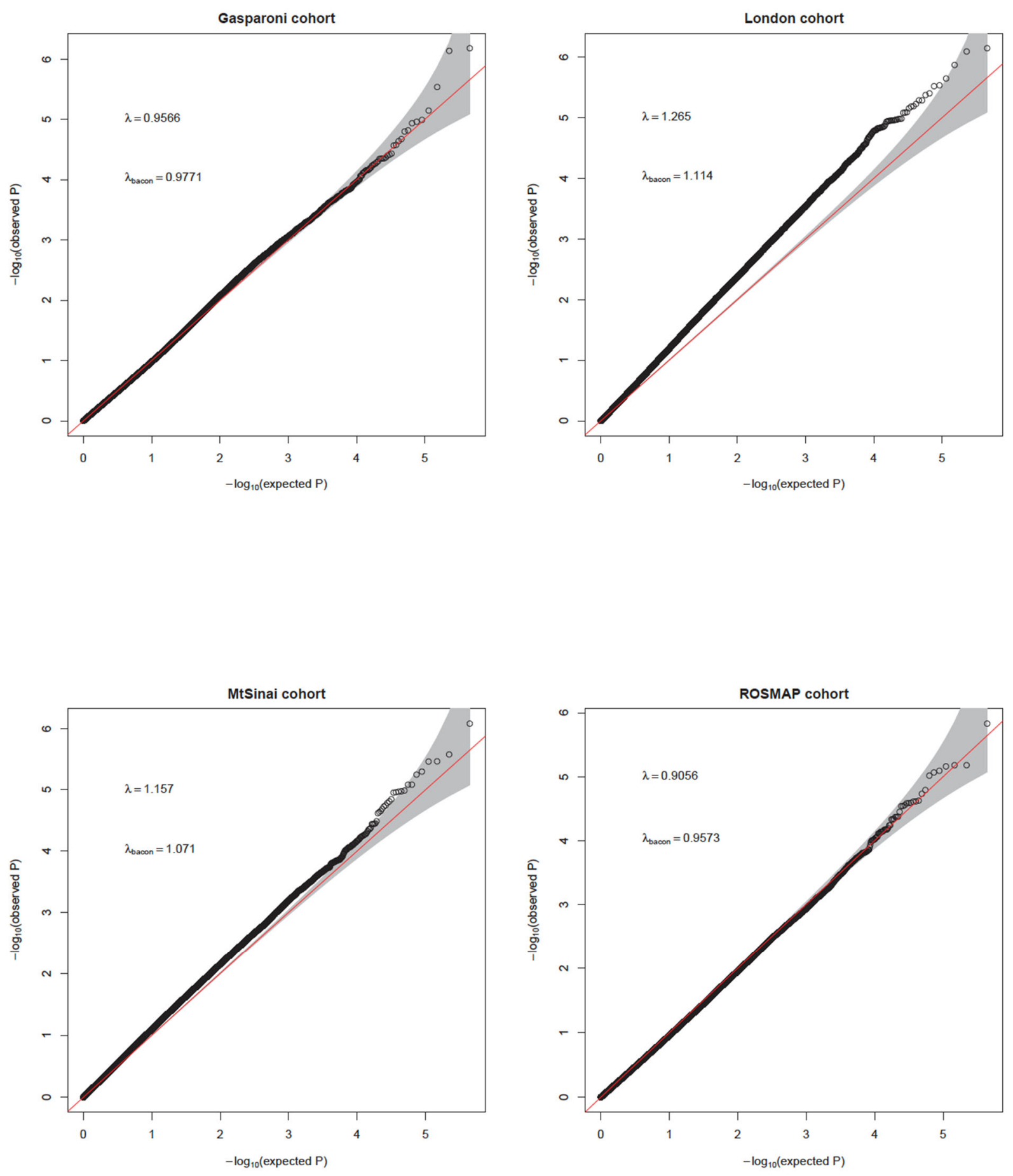
Supplementary Table 2 Enrichment of FDR significant CpGs and CpGs located within FDR significant DMRs with positive and negative effect estimates in various $(A)(B)$ genomic features and $(C)(D)$ chromatin states. ${ }^{* * *}$ indicates $P$ value $<0.001,{ }^{* *}$ indicates $P$-value $<0.01,{ }^{*}$ indicates $P$-value $<0.05$

xiv preprint doi: https://doi.org/10.1101/2021.03.01.21252029; this version posted March 2, 2021. The copyright holder for this preprir ich was not certified by peer review) is the author/funder, who has granted medRxiv a license to display the preprint in perpetuity.

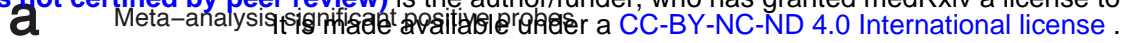

All probes $(n=464371) \quad$ Significant $w /$ Positive estimate in female $(n=451) \quad$ Significant $w /$ Positive estimate in male $(n=218)$

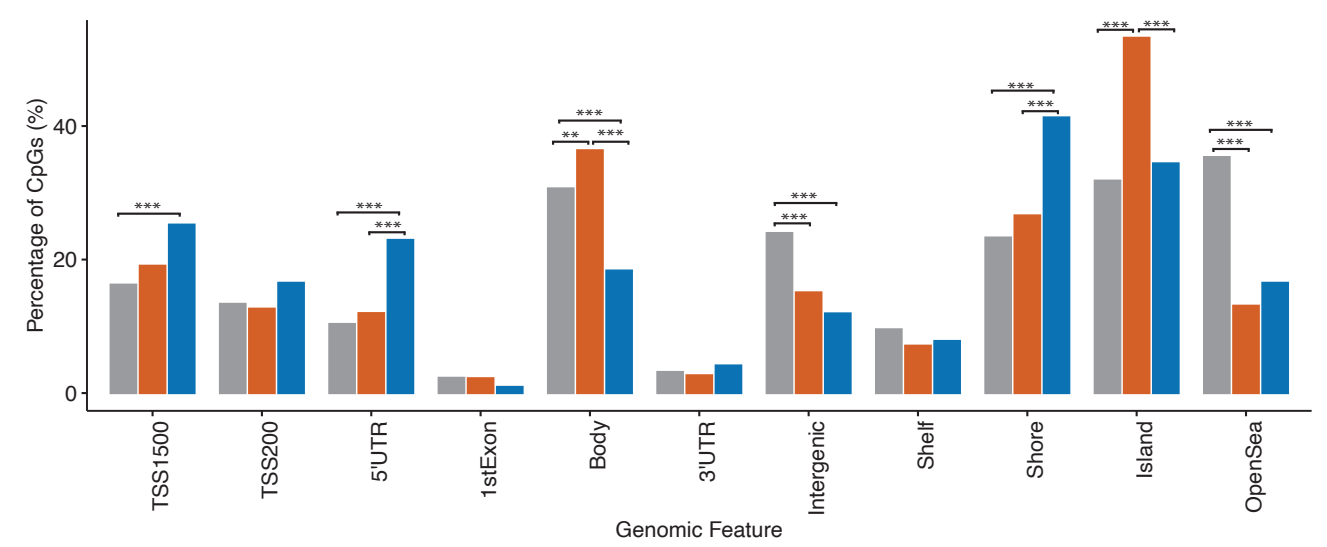

b Meta-analysis significant negative probes

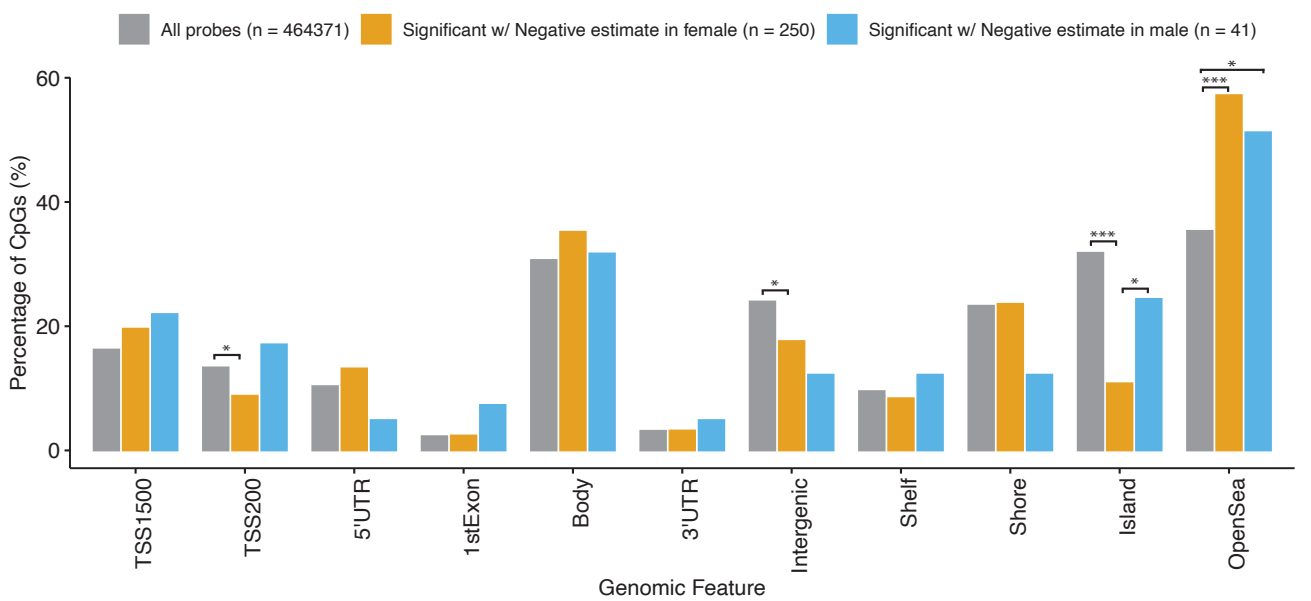

C Meta-analysis significant positive probes

ChroMHMM: E073 - 15 coreMarks segments

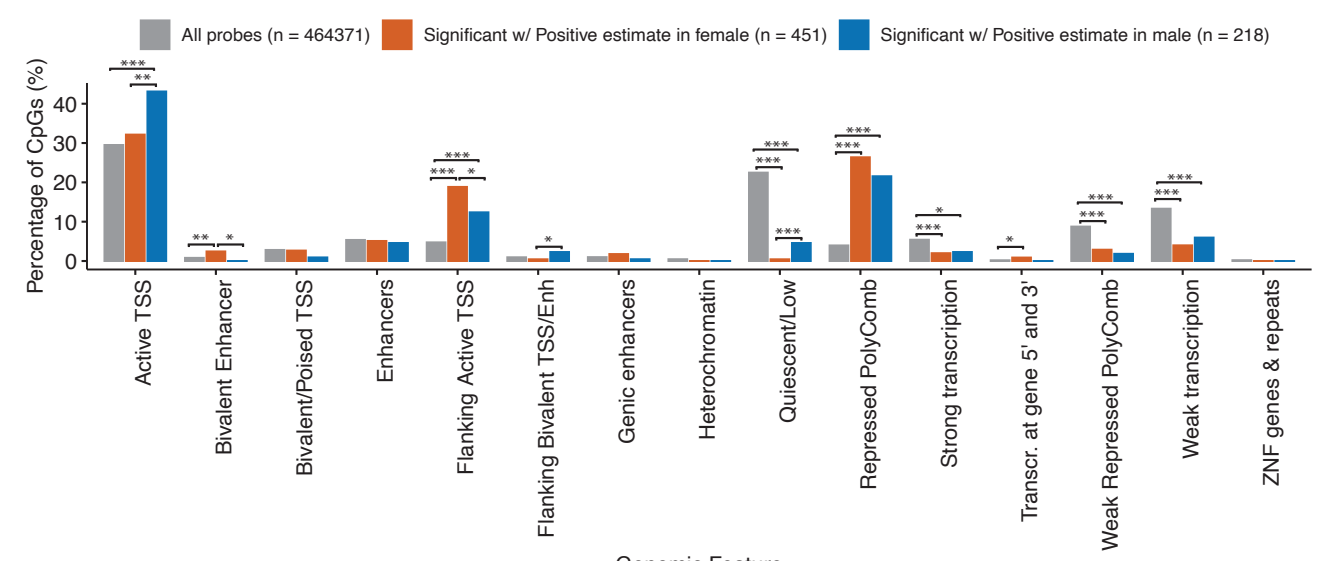

d Meta-analysis significant negative probes

ChroMHMM: E073 - 15 coreMarks segments

All probes $(n=464371) \quad$ Significant $w /$ Negative estimate in female $(n=250)$

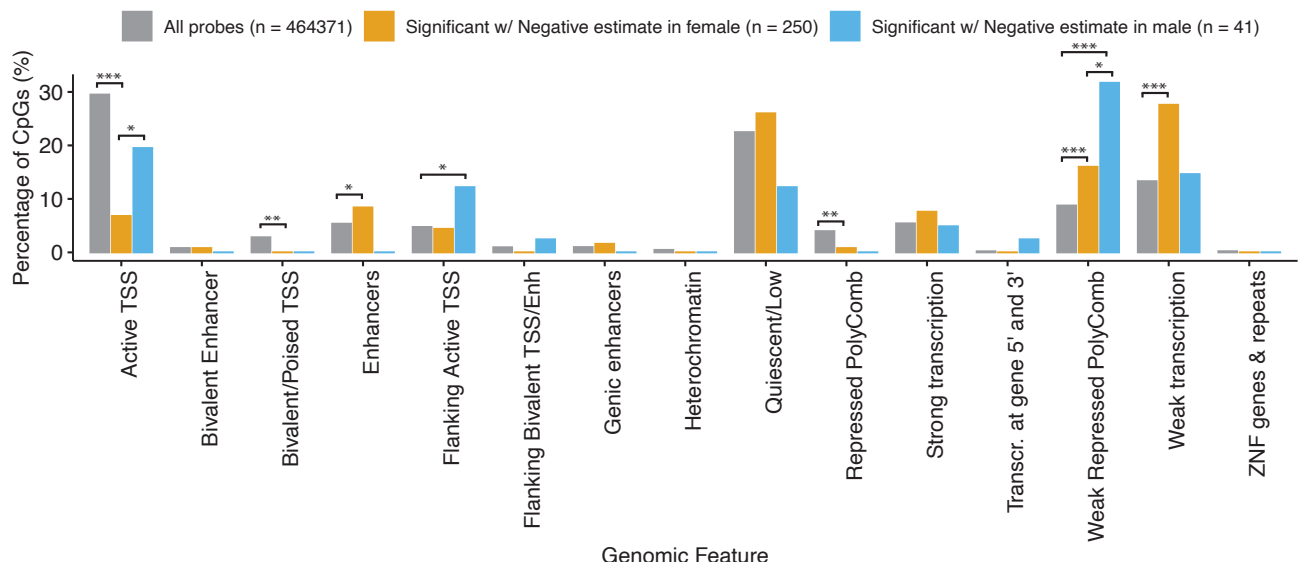


medRxiv preprint doi: https://doi.org/10.1101/2021.03.01.21252029; this version posted March 2, 2021. The copyright holder for this preprint (which was not certified by peer review) is the author/funder, who has granted medRxiv a license to display the preprint in perpetuity.

It is made available under a CC-BY-NC-ND 4.0 International license .

Supplementary Figure 3 The TYROBP causal network.

(A) Genes with significant DNA methylation changes in female samples are enriched in the TYROBP causal network (FDR $=0.014)$.

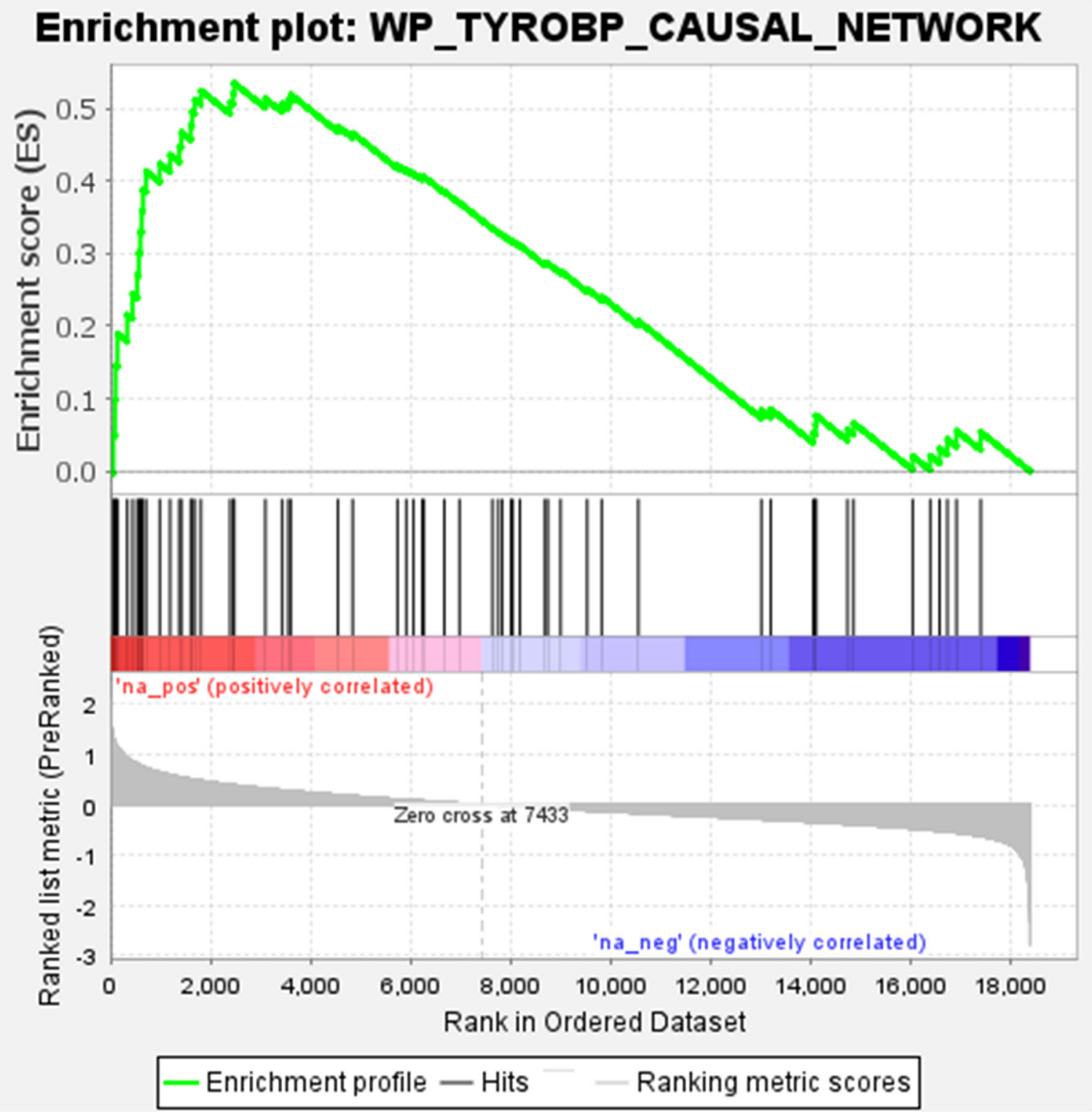


medRxiv preprint doi: https://doi.org/10.1101/2021.03.01.21252029; this version posted March 2, 2021. The copyright holder for this preprint (which was not certified by peer review) is the author/funder, who has granted medRxiv a license to display the preprint in perpetuity.

It is made available under a CC-BY-NC-ND 4.0 International license .

\section{(B) Core enrichment genes identified by GSEA.}

Orange $=$ core enrichment genes identified by GSEA in the analysis of female samples, blue $=$ core enrichment genes identified by GSEA in the analysis of male samples, and green = core enrichment genes identified by GSEA in both male and female samples analysis.

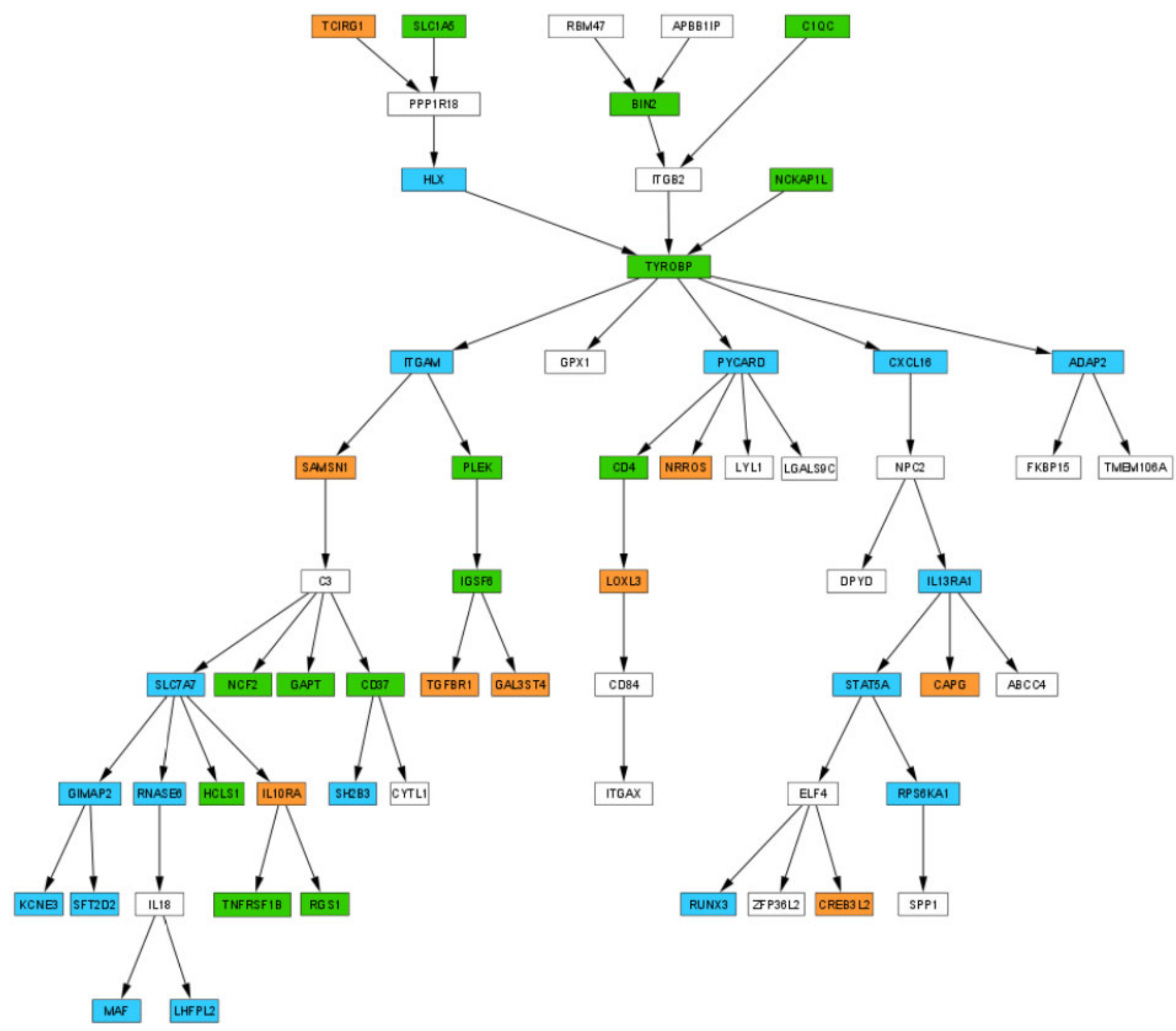


Study

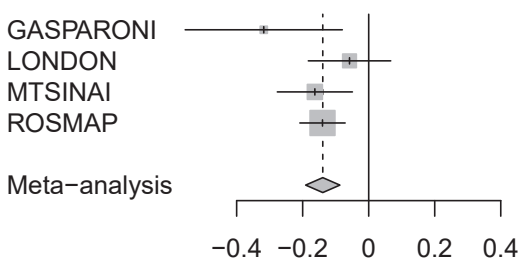

pval.female $=1.50 \mathrm{e}-07$, fdr.female $=0.003$

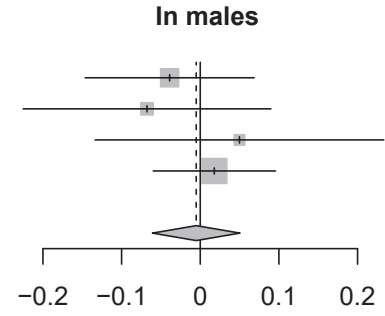

pval $\cdot$ male $=0.857$, fdr $\cdot$ male $=0.995$

\section{cg18942110(CRTC3)}

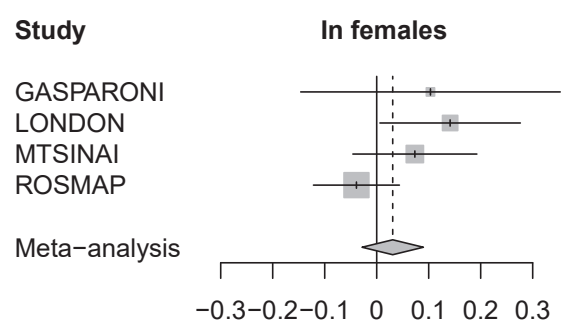

pval.female $=0.306$, fdr. female $=0.952$

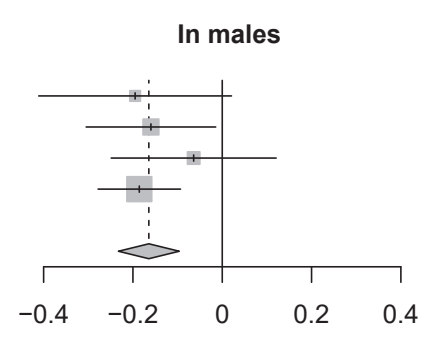

pval. male $=2.23 e-06$, fdr. male $=0.032$

\section{cg15626350(ESR1)}

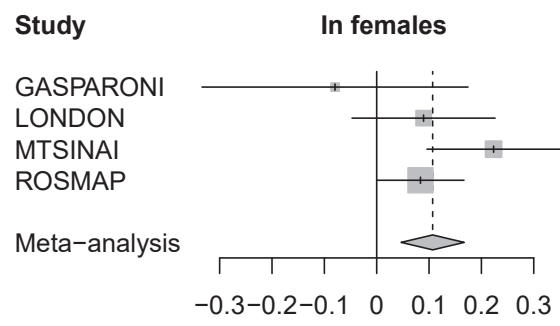

pval.female $=5.08 \mathrm{e}-04$, fdr.female $=0.164$

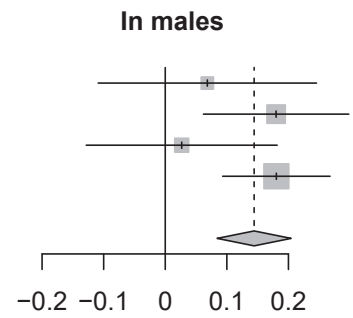

pval. male $=2.54 \mathrm{e}-06$, fdr. male $=0.033$

\section{cg25734825(TMEM39A)}

\section{Study}

GASPARONI LONDON

MTSINAI

ROSMAP

Meta-analysis

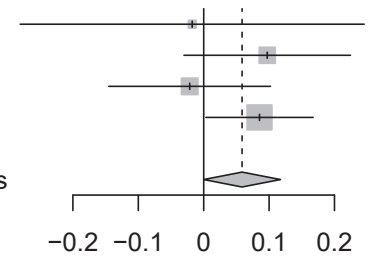

pval. female $=0.050$, fdr.female $=0.740$

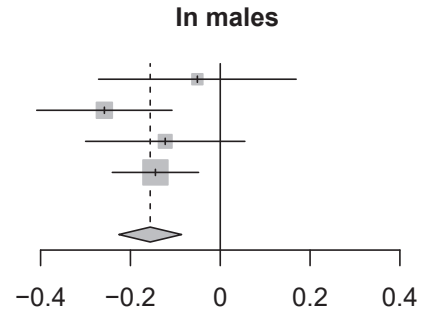

pval . male $=1.21 \mathrm{e}-05$, fdr $\cdot$ male $=0.057$

\section{cg21722170(TNXB;TNXA)}

\section{Study}

GASPARONI

LONDON

MTSINAI

ROSMAP

Meta-analysis

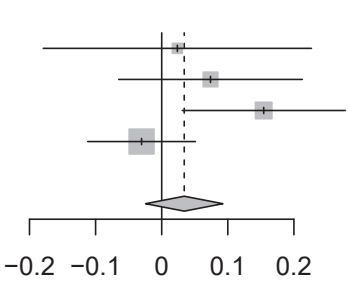

pval.female $=0.253$, fdr.female $=0.938$

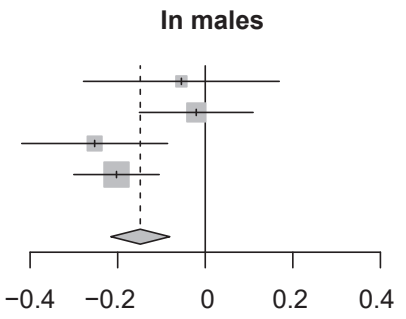

pval $\cdot$ male $=1.57 \mathrm{e}-05$, fdr $\cdot$ male $=0.061$ 